\title{
Depositional history and provenance of cratonic 'Purana' basins in southern India: A multipronged geochronology approach to the Proterozoic Kaladgi and Bhima basins
}

\author{
Sojen Joy ${ }^{1}$, Sarbani Patranabis-Deb ${ }^{2}$, Dilip Saha ${ }^{2}$, Hielke Jelsma ${ }^{1,3}$, Roland Maas ${ }^{4}$, Ulf Söderlund ${ }^{5,6}$, \\ Sebastian Tappe ${ }^{1,7}$, Gert van der Linde $^{1}$, Amlan Banerjee ${ }^{2}$, Unni Krishnan ${ }^{1}$
}

1. De Beers Group Exploration, 59 Crownwood Road, Johannesburg, South Africa

2. Geological Studies Unit, Indian Statistical Institute, Kolkatta, India

3. Anglo American Group Discovery and Geosciences, 45 Main Street, Johannesburg 2001, South Africa

4. University of Melbourne, Australia

5. Department of Geology, Lund University, Solvegatan, 12 SE-22362, Lund, Sweden

6. Department of Geosciences, Swedish Museum of Natural History, Stockholm, Sweden

7. Department of Geology, University of Johannesburg, Auckland Park 2006, South Africa

Corresponding author: Sojen Joy, De Beers Group Services, Group Exploration, Johannesburg, South Africa. Email: sojen.joy@debeersgroup.com, Phone: +27 11 3093977

\section{ABSTRACT}

Peninsular India is a collage of Archaean cratonic domains separated by Proterozoic mobile belts. A number of cratonic basins, known as "Purana basins" in the Indian literature, formed in different parts of the Indian Peninsula during extensional tectonic events, from Paleoproterozoic through Neoproterozoic times. In this contribution we present a diversity of new geochronological data for different units within the Kaladgi and the Bhima basins, which overlie the Western and Eastern Dharwar cratons respectively. The new geochronology data are discussed in terms of depositional

This is the author manuscript accepted for publication and has undergone full peer review but has not been through the copyediting, typesetting, pagination and proofreading process, which may lead to differences between this version and the Version of Record. Please cite this article as doi: $10.1002 / \mathrm{gj} .3415$

This article is protected by copyright. All rights reserved. 
history and provenance of these poorly understood Proterozoic intra-cratonic basins. For the Kaladgi Group, a U-Pb baddeleyite age of $1861 \pm 4 \mathrm{Ma}$ obtained for a dolerite dyke intruding the Yendigere Formation is used to constrain the minimum age of deposition of the lower Kaladgi Group. This result demonstrates that this part of the succession is comparable in age to the Papaghni Group of the Cuddapah basin, heralding onset of Purana sedimentation at ca. $1900 \mathrm{Ma}$. The detrital zircon populations from the clastic rocks of the Kaladgi and Bhima basins show unique and distinct age patterns indicating different source of sediments for these two basins. Paleocurrent analysis indicates a change in provenance from south or southeast to west or northwest between the Kaladgi and Bhima clastic sedimentation. New U-Th$\mathrm{Pb}$ and $\mathrm{Rb}-\mathrm{Sr}$ radiometric dates of limestones and glauconite-bearing sandstones of the Bhima Group (Bhima basin) and the Badami Group (Kaladgi basin) indicate deposition at around 800-900 Ma, suggesting contemporaneity for the two successions. Thus, the unconformity between the Kaladgi Group and the overlying Badami Group represents a time gap of up to 1000 Myr. These new results demonstrate the complex multi-stage burial and unroofing history of the Archaean Dharwar craton throughout the Proterozoic, with important implications for exploration of metal deposits and diamonds in Peninsular India.

Keywords: Dharwar Craton, Geochronology, Proterozoic basin analysis, Purana, RbSr Glauconite, U-Th-Pb and Rb-Sr Carbonate, U-Pb Baddeleyite and Zircon, mafic dykes. 


\section{INTRODUCTION}

Peninsular India or the Indian Shield is a collage of Archaean lithospheric fragments or cratonic domains (Pandey and Agrawal, 1999; Rogers, 1996; Saha et al. 2016), which preserve the records of geologic events since the Paleoarchaean. The combined Indian Shield is markedly anisotropic in terms of lithosphere architecture and inhomogeneous in terms of petrology and structure. It is divided into two major cratonic blocks, the Northern Indian Block (NIB) and Southern Indian Block (SIB) (Radhakrishna \& Naqvi 1986; Zhao et al. 2004), which are joined along a 1600 km long Proterozoic orogenic belt known as the Central Indian Tectonic zone (CITZ) (Acharyya, 2003; see also Saha et al. 2016). The Aravalli and Bundelkhand cratons are considered constituent parts of the NIB, and amalgamated by c. $3.3 \mathrm{Ga}$ (Mondal, 2009). The Dharwar (including western and eastern Dharwar and Southern Granulite Terrain), Bastar and Singhbhum cratons are considered constituent parts of the SIB and amalgamated by c. 2.5 Ga (French et al. 2008; Meert et al. 2010; Saha and Mazumder, 2012).

During post Archaean times, the craton underwent extension, allowing the onset of formation of Proterozoic basins in different parts of Peninsular India, commonly known as the Purana basins (meaning ancient or old in Sanskrit, Holland, 1907). The Purana basins are repositories of virtually un-metamorphosed and mildly deformed sedimentary successions of significant thicknesses, with a negligible component of volcanic input. The Purana successions are thought to have been deposited over a 
long time span from Paleoproterozoic (c. $1.9 \mathrm{Ga}$ ) to Neoproterozoic times, and constitute the most widespread pre-Gondwana intra-cratonic deposits in India. Key elements in the development of the Purana basins can be temporally correlated to the assembly and breakup of the supercontinents of Columbia, Rodinia and Gondwana (Basu and Bickford 2015, Saha et al. 2016). The Purana basins in Southern India include the Cuddapah-Kurnool basin, Pranhita-Godavari (PG) Valley basin, Kaladgi basin and Bhima basin (Figure 1). The Kaladgi basin abuts against the exposed northern boundary of the Western Dharwar craton and the Bhima basin lies at the exposed north-western boundary of the Eastern Dharwar craton. Both basins and adjoining cratons are concealed beneath Deccan basalts further north (Figure 1). The Proterozoic cratonic basins mentioned above, including the Kalagdi and Bhima basins, unconformably overlie the Archaean basement

Though a number of geochronological and geochemical studies from the Cuddapah and P-G Valley basins have been published in the last decade, very limited geochronological information is available for the Kaladgi and Bhima basins hindering their correlation with other Proterozoic basins in India, and across the globe (refer Saha et al. 2016). Two of the southern Purana basins, Kaladgi and Bhima, are the subject of the present study. Mostly clastic (Kaladgi) and carbonate (Bhima) sedimentation in these basins occurred in marine (predominantly shallow water) and coastal environments. Here we present an integrated analysis of stratigraphy, depositional processes, depositional systems, provenance and geochronology of the intra-cratonic Kaladgi and Bhima basins. 


\section{GEOLOGY AND STRUCTURE -BACKGROUND}

\subsection{Kaladgi Basin}

The Kaladgi basin covers an area, of about $8000 \mathrm{~km}^{2}$ with a strike extent of $\sim 200 \mathrm{~km}$ and maximum exposed width of $\sim 100 \mathrm{~km}$. The maximum aggregate thickness of the sedimentary succession is $\sim 3900 \mathrm{~m}$ (Dey 2015; Jayaprakash et al. 1987; Radhakrishna and Vaidyanadhan, 1994). Parts of the basin (in the north and west) are concealed under the Deccan traps but crop out through numerous inliers of the trap (Raha and Sastry, 1982). Metasediments of the Dharwar Supergroup, namely the Hungund schists (greenstones), and granite gneisses of the Western Dharwar craton form the basement for the Kaladgi basin sedimentation. The succession is divided into two groups, the Kaladgi Group and the Badami Group in stratigraphic order, separated by an angular unconformity (Figure 2). The Kaladgi Group is further sub-divided into two sub-groups, represented by two distinct fining-up cycles of sedimentation (Dey 2015; Jayaprakash et al. 1987). The lower cycle comprises the Lokapur Subgroup (2750 m) and the upper cycle the Semikeri Subgroup (1150 m).

We restrict ourselves to the basal successions of the Kaladgi and Badami Groups, namely the Ramdurg and Kerur Formations, aimed at delineating the timing of basin opening, initial stage of sedimentation and provenance source components, which 
are described here in more detail, augmented with our observations during geological field work in 2012-2013. The general character of the other formations within the Kaladgi and Badami Groups is briefly indicated in Figure 2 and are summarised in Saha et al. (2016)

\subsubsection{Ramdurg Formation, Kaladgi Group}

The lower part of the Ramdurg Formation ( -414 m thick) preserves poorly sorted, polymodal, very coarse- to fine-grained quartz arenite, locally pebbly and arkosic. Lenticular bodies of conglomerates are also present in the lower part of the succession (Dey, 2015; Jayaprakash et al. 1987). The pebbles are mostly of vein quartz, jasper, granite, as well as minor quartzite and hematite (Figure 3a, 3b). A rare quartz-feldspar rock fragment (possibly of felsic tuff (or aplite)) was also noted with less than $10 \%$ of the quartz grains showing overgrowths. All indications are that this is petrologically a first-cycle arenite, confirming the erosional nature of the nonconformity below. In contrast, the middle part of the Ramdurg Formation, shows medium-grained, moderately sorted quartz arenite with a few chert clasts. Quartz grains are angular in shape often with first cycle overgrowth. The uppermost part of the succession (Saundatti Member, Jayaprakash et al. 1987) preserves medium to fine grained, moderately sorted quartz arenite with a few medium grained laminae with rounded grains, some with high sphericity (Figure 3c).

\subsubsection{Kerur Formation, Badami Group}


The Kerur Formation ( 285 m thick), of the Badami Group, unconformably overlies the Kaladgi Group and passes up to the Katageri Limestone with a sharp contact (Dey, 2015; Saha et al. 2016; Jayaprakash et al. 1987). The Kerur Formation consists mostly of mineralogically and texturally mature silica-cemented mediumgrained sandstone (with subordinate conglomerate), siltstone and shale. The lower part of the Kerur Formation is a very poorly sorted, chert pebble breccia, with poorly sorted, medium- to coarse-grained sandy matrix. Matrix grain sizes range from $\leq 10$ $\mu \mathrm{m}$ to $\gg 2 \mathrm{~mm}$; large grains are well rounded, whereas small grains are very angular. A few chert pebbles/grains have veins and pockets of coarser $(-20-30 \mu \mathrm{m})$ quartz that may have precipitated in the original grains, i.e. in the parent rock. The matrix is highly ferruginous and locally clayey. The upper part is a medium- to coarse-grained, moderately sorted sub-arkose to arenite, with monomineralic nonundulose quartz predominating over polycrystalline quartz grains. While (K)-feldspar is both altered and fresh with 5\% microcline, there is pervasive quartz cement with abundant overgrowth on quartz grains.

The sandstone outcrops as isolated or stringed hills in a large lowland of mudstone. The studied litho-succession is divided into two major units. The lower unit, consisting of cross-stratified, coarse- to medium-grained, feldspathic sandstone with a few scattered pebbles and lenticular beds of conglomerate. The deposits occur as shallow, fining upward wide channel fill bodies (1-2 m deep) with a high width/depth ratio (5:1), which are commonly amalgamated into thick sheets. The dominant 
paleoflow is toward SW. The upper unit constituting the main body of the Kerur Formation and consisting of_medium-grained, very well-sorted, quartzarenite $(<5 \%$ mud) and feldspathic sandstone, locally with coarser pockets and thin beds (10-20 $\mathrm{cm}$ ) with isolated pebbles. They form positive-relief sand bodies, which are made up of "wavy parallel" or "pinch and swell" beds (thickness varies between 0.5-2 m). Most of the beds pinch out laterally within $5-10 \mathrm{~m}$, but a few thick amalgamated beds could be traced laterally for over $50 \mathrm{~m}$ or more along the strike. The upper surfaces of the sandstone bodies are slightly convex upward and slope away in all directions from the crest region forming shoaling up linear bars and ridges, commonly more than a kilometer in length, and separated from each other by muddy to low-energy sandy deposits. Upper surfaces of a majority of thick beds show development of wave ripples and dunes, locally with marked concentrations of very well-sorted and well-rounded coarse sand and granules in the troughs. The dunes are generally symmetrical to slightly asymmetrical, straight to sinuous crested, with low amplitudes and broad wave lengths, and commonly exhibiting tuning fork bifurcations (Figure 3d). Dune crests are generally parallel to the trends of the linear bars, with sharp or round crests, and with smaller ripples within the troughs of larger ripples. The dunes show discordant chevrons or vertically upbuilding bundles of strata, off-shooting and mud-draping foresets, or bidirectional foresets. The trough cross-strata (1-2 m wide), occur as cosets (0.5-1.5 m thick) with well-preserved bimodal, bipolar paleocurrent direction (Figure 2, 6) and reactivation surfaces. Herringbone cross-stratification, are locally seen. 
The facies in the lower part of the succession was deposited in braided streams (Mukhopadhyay et al. 2019). The upper facies was deposited by large, migrating bed forms in high energy wave-reworked zones. Deposition involved repetitive cycles of tide-dominated to wave-dominated sedimentation, possibly within macro tidal range, stacking tidal dunes into sand ridges (Patranabis-Deb 2015). Bipolar, bimodal distribution of foreset azimuths, with the modes between NE and SW indicate that these sand bodies developed as transverse to shore parallel bars and ridges.

\subsection{Bhima Basin}

The NE-SW trending Bhima basin $\left(5200 \mathrm{~km}^{2}\right)$ is the smallest Proterozoic basin in India and unconformably overlies the Archaean basement of the eastern Dharwar craton (Figure 1). Much of the basin is covered by end-Cretaceous Deccan Trap basalts and associated sediments. The sedimentary succession is thin compared to other Purana basins, with a maximum thickness of $273 \mathrm{~m}$ (Mishra et al. 1987). The Bhima Group comprises two subgroups, Sedam and Andola, which are further subdivided into five units of formation status representing clastic-carbonate cycles (Jayaprakash et al. 1987; Figure 4). The Sedam Subgroup comprises a lower unit, the Rabanapalli Formation and an upper unit, the Shahabad Formation. The Rabanapalli Formation includes conglomerates, granulestone, pebbly sandstones and quartz arenites with thick bedded planar and cross-stratified sandstones alternating with planar parallel-bedded types, which reflect shallow shelf environment 
of deposition (Figure 5a). The overlying Shahabad Formation is a limestone-marl rhythmite ("flaggy limestone") (Figure 5b, 5c). Detailed facies classification and cyclicity analysis of the Shahabad Limestone shows that it represents a non-rimmed carbonate platform (Saha et al. 2016). On the basis of field evidence, the succession may be classified into two major facies associations, representing shallow water mixed carbonate-siliciclastic stage, and a major transgressive stage depositing sand free black limestone (Saha et al. 2016; Figure 5d). Facies analysis revealed a major transgression and deepening of the basin with development of euxinic condition and deposition of black limestone (Chilingar et al. 1967; Patranabis-Deb et al. 2016). Authigenic pyrite within black carbonaceous limestone also points towards development of an anoxic ocean basin during maximum transgression (Wignall 1994). Deposition of the Halkal Shale may be taken as the cause of demise of the

carbonate platform. However, the carbonate factory resumed its production with a drastic change in the environment, reducing the siliciclastic input, which is represented in the rock record by sharp contact between the two formations (Figure $5 b)$.

\subsection{Paleocurrent Analysis}

Palaeocurrent analysis of the Ramdurg Formation of the Kaladgi basin indicates northwest to northerly flow (Figure 2, 6). However, during deposition of the Kerur Formation of the unconformably overlying Badami Group, the sediment flow pattern changed towards southwest and the upper parts showing strong bimodality (SW-NE) 
suggesting that tidal activity played a major role during deposition of the upper part of the Kerur Formation.

The Rabanapalli Formation of the Bhima Group show paleoflow towards northeast and southeast (Figure 4,6). Overall changes in the paleocurrent direction during the Bhima indicate a major shift of the provenance for the Bhima Group to west.

\section{GEOCHRONOLOGY}

Work over the last decade has established that several Purana basins in India had opened at different times in the Proterozoic. However, the lower and upper age limits

of major depositional sequences in separate basins are largely unconstrained, impeding the evaluation of their global significance. The question of the upper age limit of Purana successions, and the possibility of their continuity into the late Neoproterozoic or even into the Cambrian has been debated for a long time (Saha et al. 2016 and references therein). Recently, U-Pb zircon ages from tuffs sampled from the Chhattisgarh and Indravati basins have led to a new hypothesis suggesting closure of major cycle of sedimentation of at least these basins is at ca. $1000 \mathrm{Ma}$ (Bickford et al. 2011; Mukherjee et al. 2012), and at ca. 700 Ma for the P-G Valley basin (Joy et al. 2015).

Geochronological data from the Kaladgi and Bhima basins are scant and mostly unreliable. Based on the stromatolites within Kaladgi Group, Sharma and Pandey (2012) have proposed an Orosirian (Late Paleoproterozoic) age. The depositional 
age of the shales from Bagalkot Group, based on the model $\mathrm{Rb}-\mathrm{Sr}$ isotopic age calculated with respect to CHUR (i.e., a chondritic Earth model) is suggested to be younger than $1800 \pm 100$ Ma (Padmakumari et al. 1998, Sambasiva Rao et al. 1999). The Mallapur mafic dykes post-dating the deformation of the Kaladgi Group have been recently dated using whole rock ${ }^{40} \mathrm{Ar} /{ }^{39} \mathrm{Ar}$ as $1154 \pm 4$ Ma (Pillai et al. 2018). Based on this age and the geological relationships, Pillai et al (2018) propose that the overlying Badami Group is younger than 1000 Ma. A Neoproterozoic age for the Shahabad Limestone, as proposed by Kale and Phansalkar (1991), is consistent with the chemostratigraphy and carbon isotope composition (Kumar et al. 1999; Nagarajan et al. 2008).

However, there are other proponents for an older age for the Bhima Group. Dongre et al. (2008) suggested that the Bhima basin is older than $1100 \mathrm{Ma}$, and Absar et al. (2016) proposed that it is older than 1300 Ma. A late PaleoproterozoicMesoproterozoic age has been proposed by Augustine et al. (2015). It must be noted that none of these models are based on direct geochronological evidence.

\section{SAMPLES FOR THIS STUDY}

This study is based on a diverse suite of 29 samples from the Kaladgi and Bhima basins (Figure 7, Table 1). Samples were collected from various lithological units to address specific research questions (Table 1). 


\subsection{Kaladgi and Badami Groups}

For the Kaladgi basin, we report detrital zircon U-Pb ages in a conglomerate (EHV678) from the Ramdurg Formation and for three arenitic sandstones (EHV680, $683,689)$ in the Kerur Formation. In addition, U-Th- $\mathrm{Pb}$ isotope systematics were studied in multiple specimens of limestone (EHV679) from the Katageri Limestone, the youngest preserved stratigraphic unit of the basin. Finally, a high-precision U-Pb age was obtained for dolerite (EHV667) which cuts argillites of the Yendigere Formation. Estimates of depositional ages (i.e. maximum depositional ages based on the youngest detrital zircon ages; diagenetic overprinting in limestones; minimum ages based on dating of a crosscutting dolerite dyke) derived from these samples (Table 1) were conducted to provide radiometric age constraints for sediment deposition at the base and top of the Kaladgi basin sequence.

\subsection{Bhima Group}

For the Bhima basin, detrital zircon U-Pb ages were studied in three arkosic sandstones (EHV951, 953 and 962) of the Rabanapalli Formation at the base of the Bhima Group (Figure 7). U-Th-Pb and Rb-Sr isotope systematics were examined in 13 samples of Shahabad Limestone and in 3 samples of Katamdevarahalli Limestone (Table 1, Figure 7). In addition, $\mathrm{Rb}-\mathrm{Sr}$ ages were obtained from glauconite in glauconitic sandstone intervals (EHV956, 957) within Korla shale of the Rabanapalli Formation (Figure 7). 


\subsubsection{Sample EHV956}

Petrographically, EHV956 is a very thinly bedded sandstone ranging in colour from light brownish grey (quartz-rich layers) to greyish green (glauconite-rich layers) as illustrated in Figure 8. Abundant sub-rounded to sub-angular quartz ( 70 vol\%) and subordinate feldspar plus lithic fragments ( -5 vol\%) show a wide range in grain size (250-1250 $\mu \mathrm{m})$ and are supported within a matrix ( 25 vol\%) predominantly composed of coarse-grained dolomite (500-1250 $\mu \mathrm{m})$ and glauconite $(400-1500 \mu \mathrm{m})$. Rare disseminated magnetite $(<400 \mu \mathrm{m})$ appears to be an alteration product of glauconite, given the close textural proximity.

Based on intergrowth textures, cement-forming dolomite and glauconite appear to have precipitated simultaneously, although dolomite also forms by replacement of glauconite (Figure 8). The anomalously weak pleochroism of the relatively large and fresh glauconite grains indicates that they contain cryptocrystalline domains.

\subsubsection{Sample EHV957}

Petrographically, sample EHV957 represents a very thinly bedded to laminated intercalation of sandstone (brownish grey) and mudstone (greyish red), with individual layers being $<5 \mathrm{~mm}$ thick (Figure 9). Sandstone layers consist predominantly of subrounded to angular quartz ( 90 vol\%) and subordinate feldspar and mica grains ( $\sim 5$ vol\%), with an overall range in grain size between 0.1 and 0.75 $\mathrm{mm}$ (fine- to coarse-grained sand). The poorly-sorted, immature sandstone layers contain 3-5 vol\% authigenic (early diagenetic) glauconite (250-750 $\mu \mathrm{m}$, rarely to 
$1000 \mu \mathrm{m})$. Glauconite occurs primarily as peloids with sub-rounded shapes and smooth margins, which is typical for authigenic crystal growth (Chafetz and Reid, 2000; Odin and Matter, 1981). Kinked glauconite grains are rare (Figure 9). Glauconite appears to be fresh to slightly altered, and the absence of strong pleochroism indicates a micro- to cryptocrystalline nature of individual grains. Secondary magnetite and limonite may coat individual glauconite grains and also occur along cracks within glauconite grains. All grains within the sandstone layers and stringers, including glauconite, are set in a Fe-stained dolomite matrix (matrixsupported fabric). As in sample EHV956, there is evidence for matrix carbonates successively replacing the glauconite (Figure 9).

An authigenic origin of the glauconite grains is supported by the rare occurrence of slender $\leq 0.1 \mathrm{~mm}$ long apatite inclusions (i.e., needles). Such brittle apatite needles would not stay intact during grain transport and, thus, their presence supports an detrital origin of the host glauconite grains. Bedding-parallel stylolites comprising Festained clay minerals indicate that significant compaction and associated fluid flow occurred during diagenesis (Figure 9).

\subsection{Basement}

Sample EHV954 of the biotite-hornblende granite exposed below the Muddebihal Conglomerate, Rabanpalli Formation was collected close to the western outcrop extent of the Bhima basin, for comparative purpose (see Figure 7). 


\section{GEOCHRONOLOGY METHODS}

\subsection{U-Pb Zircon (LA-ICPMS)}

The samples collected (ca. $5 \mathrm{~kg}$ ) were crushed at the De Beers sample treatment centre, Bangalore, India. The treatment process consisted of crushing, screening, standard dense media separation (DMS), low intensity magnetic separation and heavy liquid separation through a lithium heteropolytungstate solution (LST). The resultant heavy mineral concentrate was partitioned to two size fractions viz. $(+0.3$ $0.5 \mathrm{~mm})$ and $(+0.5-1.0 \mathrm{~mm})$. The zircons were recovered and were analysed at the De Beers analytical centre, Johannesburg. The handpicked zircons were mounted in $25 \mathrm{~mm}$ diameter epoxy mounts and polished to fully expose the midsection of the grains. Epoxy mount surfaces were cleaned using 96\% ethanol and were put in a vacuum chamber to ensure sufficient outgassing of the epoxy.

The U-Pb isotope analyses were done at the De Beers Exploration Laboratories, using a New Wave 193 Excimer laser ablation system equipped with a Large Format ablation cell and interfaced with a Thermo Fisher X-Series 2 quadrupole ICP-MS. The ICP-MS instrument was optimised for maximum sensitivity, stability and low background using the NIST-610 glass standard. Ablations were carried out in a helium atmosphere, with a laser spot size of $35 \mu \mathrm{m}$. Ablation sites were placed at the centre of the zircon grains and away from cracks. Due to the small grain size, only one spot analysis was carried out per grain, and it was not possible to carry out analyses of thin zircon rims. Unknowns and standards were ablated for 60 seconds, 
followed by generous washouts of 5 minutes. The masses ${ }^{206} \mathrm{~Pb},{ }^{207} \mathrm{~Pb},{ }^{208} \mathrm{~Pb},{ }^{235} \mathrm{U}$, ${ }^{238} \mathrm{U}$ and ${ }^{232} \mathrm{Th}$ were measured for $50 \mathrm{~ms}$ each, yielding a total sweep time of 300 ms. Data reduction was done using the GLITTER Laser Ablation data reduction software (Van Achterbergh et al. 2001). The GJ-1 zircon standard (slightly discordant, ID-TIMS ${ }^{207} \mathrm{~Pb} /{ }^{206} \mathrm{~Pb}$ age $608.5 \pm 0.4 \mathrm{Ma}$, Jackson et al. 2004) was used as the calibration standard (Annexures 1, 2). Concordia diagrams and age calculations were performed using IsoPlot v. 3.70 (Ludwig, 2003). BSE images of the analysed zircon grains (Figure 10) were captured using a Cameca SX100 Electron Probe Micro Analyser. The U-Pb concentrations (in ppm) determined for the different runs are comparable to the TIMS results of Jackson et al. 2004 (Annexure 1). The U$\mathrm{Pb}$ concordia diagram of combined analysis of the GJ-1 is presented as Annexure 2 and the intercept age of $600 \mathrm{Ma}$ (MSWD 0.2) is comparable to the ID-TIMS age of $608.5 \pm 0.4 \mathrm{Ma}$ (Jackson et al. 2004).

\subsection{U-Pb Baddeleyite (ID-TIMS)}

Sample EHV667 was processed for baddeleyite using the water-based separation method of Söderlund and Johansson (2002) at Lund University. The sample was crushed and milled to powder, before the powder was immersed in water and processed on a Wilfey water-shaking table. The baddeleyite grains were handpicked using tweezers under a stereomicroscope after magnetic separation of the collected high-density minerals. From the bulk of baddeleyite grains, the best-quality grains were loaded into three Teflon capsules, with 3-6 grains each. 
After transferring and washing the baddeleyite fractions in ultrapure $\mathrm{H}_{2} \mathrm{O}$ and $\mathrm{HNO}_{3}$, a small amount of a ${ }^{236-233} \mathrm{U}_{-}{ }^{205} \mathrm{~Pb}$ tracer solution and 10 drops of $\mathrm{HF}: \mathrm{HNO}_{3}(10: 1)$ was added to the Teflon capsules. The baddeleyite grains were then completely dissolved in an oven after three days at ca. $210^{\circ} \mathrm{C}$. Further details are given by Söderlund and Johansson (2002) and Olsson et al. (2010).

Mass spectrometry analysis was performed on a Thermo-Finnigan TRITON mass spectrometer (TIMS) at the Swedish Museum of National History in Stockholm with a Secondary Electron Multiplier (SEM) and RPQ- filter. IsoPlot macro software from Ludwig (2003) and uranium decay constants from Jaffey et al. (1971) were used for data reduction and age calculations. Initial common $\mathrm{Pb}$ corrections were done using the isotopic compositions from the terrestrial $\mathrm{Pb}$ isotope evolution model of Stacey and Kramers (1975).

\subsection{Pb-Sr isotopic compositions of limestones and $\mathrm{Rb}-\mathrm{Sr}$ ages for} glauconite

Whole rock $\mathrm{Pb}-\mathrm{Sr}$ isotope data for limestones and $\mathrm{Rb}-\mathrm{Sr}$ glauconite ages were acquired at The University of Melbourne, Australia. Limestone chips powdered in agate (7 specimens from EHV679, 37-64 mg) were dissolved using hydrofluoric and nitric acid. Additional splits from these samples (70-100 mg powder) were reacted with warm $2 \mathrm{M}$ nitric acid $\left(60^{\circ} \mathrm{C}, 10 \mathrm{hrs}\right)$ to extract a carbonate fraction, with the aim of reducing or eliminating the effect of detrital impurities on $\mathrm{U}-\mathrm{Th}-\mathrm{Pb}$ and $\mathrm{Rb}-\mathrm{Sr}$ isotope results. Carbonate fractions in sixteen more reactive Bhima Group limestones were extracted with cold $2 \mathrm{M}$ nitric acid. Each of the sample solutions (8 
bulk dissolutions, 24 carbonate fractions) was split for trace element and isotopic analysis ( $\mathrm{Pb}$ isotopes only for Kaladgi basin samples, $\mathrm{Pb}-\mathrm{Sr}$ for Bhima basin samples) by quadrupole ICP-MS and multi-collector ICP-MS, respectively.

Glauconite from two glauconitic sandstones (glauconite-rich EHV956, glauconitepoor EHV957) was separated using magnetic separation. Carbonate impurities and composites in EHV956 and mica flakes in EHV957 were removed by handpicking to produce visually pure glauconite which were cleaned with hot distilled water and dried. Four splits of EHV956 glauconite $(20-27 \mathrm{mg})$ and 2 splits of EHV957 glauconite (8-12 mg) were weighed into teflon beakers and reacted with cold $2 \mathrm{M}$ nitric acid (10 mins); the leach solutions and two water rinses were stored. The glauconite residues were dissolved in $1 \mathrm{ml}$ of $3: 1 \mathrm{HF}-\mathrm{HNO}_{3}$ and pure $\mathrm{HNO}_{3}$. After preliminary checks of $\mathrm{Rb}-\mathrm{Sr}$ contents, each of the 6 residue and leachate solutions was equilibrated with $\mathrm{a}^{85} \mathrm{Rb}-{ }^{84} \mathrm{Sr}$ spike for isotope dilution $\mathrm{Rb}-\mathrm{Sr}$ dating.

$\mathrm{Pb}$ was extracted from the limestone whole rocks and carbonate fractions using a double pass $\mathrm{HBr}-\mathrm{HCl}$ chemistry on small $(0.1 \mathrm{ml})$ columns of AG1-X8 (100-200 mesh) anion resin (Kamber and Gladu, 2009; Woodhead et al. 1995). Corrections for procedural blank ( $<0.1 \mathrm{ng} \mathrm{Pb}$ ) were negligible for typical sample sizes of $\geq 100 \mathrm{ng}$. $\mathrm{Sr}$ was extracted from limestone carbonate fractions and glauconite residue-leachate pairs using a single and double pass, respectively, on small $(0.15 \mathrm{ml})$ columns of Eichrom Sr resin $(50-100 \mu \mathrm{m})$. Rb was extracted from the (now Sr-free) glauconite fractions using a cation exchange procedure (4 $\mathrm{ml}$ of AG50-X8, 200-400 mesh, see Maas et al. 2015). 
Trace element concentrations were determined on an Agilent 7700x quadrupole ICPMS, using the methods of Kamber et al. (2003). Isotopic analyses were carried out on a Nu Plasma multi-collector ICP-MS coupled to a Cetc Aridus desolvator. $\mathrm{Pb}$ isotope data were acquired using the thallium-doping technique (Woodhead, 2002) which produces external precisions of ca.0.04-0.08\% (2sd). Measured $\mathrm{Sr}$ isotope ratios were normalized to ${ }^{88} \mathrm{Sr} /{ }^{86} \mathrm{Sr}=8.37521$ and ${ }^{87} \mathrm{Sr} /{ }^{86} \mathrm{Sr}$ is reported relative to SRM987 $=0.710230$. Mass bias in Rb isotope dilution analyses was corrected using Zr-doping. The USGS basalt standard BCR-2 yields long-term averages of ${ }^{206} \mathrm{~Pb} /{ }^{204} \mathrm{~Pb}=18.758 \pm 009,{ }^{207} \mathrm{~Pb} /{ }^{204} \mathrm{~Pb}=15.619 \pm 0.010,{ }^{208} \mathrm{~Pb} /{ }^{204} \mathrm{~Pb}=38.726 \pm 0.035$ and ${ }^{87} \mathrm{Sr} /{ }^{86} \mathrm{Sr}=0.704997 \pm 42( \pm 2 \mathrm{sd})$. Broken Hill galena averages 16.004 \pm 0.006 , $15.388 \pm 0.009$ and $35.661 \pm 0.027( \pm 2 s d)$. Rb-Sr dates for GLO-1 glauconite and Mt. Dromedary (GA1550) biotite acquired with the Bhima Group glauconites yield ages of $\sim 89$ and $\sim 99 \mathrm{Ma}$, respectively. All standard results are consistent with reference values. The decay constants are ${ }^{238} \mathrm{U} 0.155125 \times 10^{-9} / \mathrm{yr},{ }^{235} \mathrm{U} 0.98485 \times 10^{-9} / \mathrm{yr},{ }^{232} \mathrm{Th}$ $0.049485 \times 10^{-9} / \mathrm{yr}$ and ${ }^{87} \mathrm{Rb} 1.395 \times 10^{-11} / \mathrm{yr}$.

\section{GEOCHRONOLOGY RESULTS}

\subsection{U-Pb Zircon Analysis}

Detrital zircon yields from seven coarse-grained clastic sedimentary rocks from the Kaladgi, Badami and Bhima groups are generally low. Many of the analysed sites are discordant, showing considerable zero-age radiogenic $\mathrm{Pb}$ loss from a dominant 2.6-2.4 Ga concordant population and, in some cases, from minor but consistent 
Meso- and Eoarchaean components. Detrital age histograms and concordia diagrams have been plotted only for analyses that are $<15 \%$ discordant, with discordance defined as $1-\left({ }^{206} \mathrm{~Pb} /{ }^{238} \mathrm{U}\right.$ Age $\div{ }^{207} \mathrm{~Pb} / 206{ }^{\mathrm{Pb}}$ Age $)$. Only the $<15 \%$ discordant analysis are used in the interpretation and discussed in the following sections. However, all the analyses are shown in the U-Pb data tables in Annexure 3.

\subsubsection{Kaladgi Group}

All 50 zircon grains recovered from conglomerate EHV678 were analysed but only 14 yielded results that passed the $<15 \%$ discordance filter used here (Annexure $3 a$ ). Most of the resultant ages cluster at $\sim 2600 \mathrm{Ma}$ and $\sim 2300 \mathrm{Ma}$ (Figure 11). The youngest age in this population is 2287 Ma. Two grains contain Archaean components ( $-3300,>4000$ Ma-very imprecise).

\subsubsection{Badami Group}

Sample EHV680, a pebbly sandstone, yielded 70 zircons (Annexure 3b). The results of 30 of the $70 \mathrm{U}-\mathrm{Pb}$ analyses passed the $<15 \%$ discordance filter. As in the Kaladgi Group, most ages cluster at $\sim 2600$ to $\sim 2350 \mathrm{Ma}$, with the youngest age at $2283 \mathrm{Ma}$. Four grains yielded Archaean ages of 3200, 3300, 3500 and $\sim 4080$ Ma (Figure 11 and Annexure 3b).

Another pebbly conglomerate/sandstone, EHV683, yielded 65 zircons of which 24 produced concordant to near-concordant U-Pb results (Annexure 3c). Most ages are 
in the range $2600-2500 \mathrm{Ma}$, with a subordinate peak at $\sim 2360 \mathrm{Ma}$, with the youngest age at $2357 \mathrm{Ma}$. Five grains yield ages at $\sim 2800 \mathrm{Ma}$ and $3300 \mathrm{Ma}$ (Figure 11).

Sixty zircons were recovered from sandstone EHV689. Twenty-one of the sixty analyses are concordant (Annexure 3d) and yield a strong age peak at $\sim 2600 \mathrm{Ma}$ and a subordinate peak at $\sim 2230 \mathrm{Ma}$. The youngest detrital zircon has an age of $2229 \mathrm{Ma}$. Four grains have Archaean ages, at $\sim 2770, \sim 3100 \mathrm{Ma}$ and $3460 \mathrm{Ma}$ (Figure 11).

\subsubsection{Bhima Group}

Sixty-three analysed zircons from arkosic grit EHV951 yielded only 17 concordant ages (Annexure 3e) which cluster at $\sim 2450$ Ma (Figure 12). The youngest age is $2347 \mathrm{Ma}$.

Thirty-six zircons from arkosic sandstone EHV953 yielded 21 concordant or nearconcordant ages clustered at $\sim 2450 \mathrm{Ma}$ (Annexure 3f, Figure 12). The youngest age is $2277 \mathrm{Ma}$.

Twenty-two analysed zircons from arkosic sandstone EHV962 yielded 10 concordant to near-concordant ages (Annexure $3 \mathrm{~g}$ ) clustered at $\sim 2530 \mathrm{Ma}$ and $\sim 2400 \mathrm{Ma}$ (Figure 12). The youngest age is $2377 \mathrm{Ma}$.

\subsubsection{Basement}

In situ U-Pb isotope results for 50 zircon from granitic gneiss EHV954 form a broad

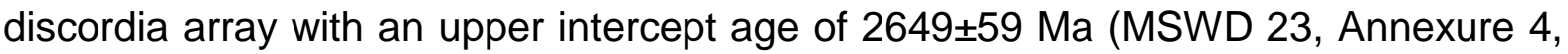


Figure 13). The upper intercept age is interpreted as the emplacement age of the granite.

\subsection{U-Pb Baddeleyite}

Sample EHV667 collected from dolerite dyke cutting the Yendigere Formation (Kaladgi Group) yielded approximately 40 brown to clear baddeleyite grains for U-Pb dating, which were analysed using Thermal Ionization Mass Spectrometry (TIMS). The grains are medium brown and clear with a size of 50-80 $\mu \mathrm{m}$ in the longest dimension. The three fractions plot less than 3\% discordant with two overlapping fractions plotting just below (ca. 1\%) the Concordia curve (Figure 14). Regression yield upper and lower intercepts of $1861.0 \pm 3.7$ and $241 \pm 310 \mathrm{Ma}$, respectively (MSWD

crystallization age of the dolerite dyke.

\subsection{U-Th-Pb and Rb-Sr isotopic compositions of limestones}

The $\mathrm{U}-\mathrm{Th}-\mathrm{Pb}$ isotopic compositions of limestones from the Kaladgi basin are listed in Table 2. U-Th-Pb isotope compositions of bulk digestions and carbonate fractions for seven sub-samples of silicified dolomitic limestone EHV679 (Katageri Limestone, Badami Group) show considerable overlap and substantial scatter (Figure 15 a, b). In the U-Pb diagram, the seven EHV679 bulk fractions define a broad linear array with a slope equivalent to $\mathrm{a}^{238} \mathrm{U} /{ }^{206} \mathrm{~Pb}$ isochron age of $0.96 \mathrm{Ga}\left({ }^{206} \mathrm{~Pb} /{ }^{204} \mathrm{~Pb}\right.$ intercept $=24.5$, Figure 15a). 
The Th-Pb isotope results for all 16 samples (13 samples of Shahabad Limestone and 3 samples of Katamdevarahalli Limestone) form a scattered but consistent trend with an apparent ${ }^{232} \mathrm{Th}-{ }^{208} \mathrm{~Pb}$ isochron age of $0.91 \pm 0.13 \mathrm{Ga}$ (Figure 16).

The Bhima Group carbonate fractions have low $\mathrm{Rb} / \mathrm{Sr}$ ratios $\left({ }^{87} \mathrm{Rb} /{ }^{86} \mathrm{Sr} 0.003-0.032\right.$, Table 2), an expected feature of unaltered limestones. Radiogenic ${ }^{87} \mathrm{Sr}$ ingrowth from this range of $\mathrm{Rb} / \mathrm{Sr}$ ratios would increase ${ }^{87} \mathrm{Sr} /{ }^{86} \mathrm{Sr}$ by only $0.00004-0.00045$ per 1 $\mathrm{Ga}$, i.e. present-day ${ }^{87} \mathrm{Sr} /{ }^{86} \mathrm{Sr}$ could be close to initial ratios if other factors (e.g. alteration, weathering) were not important. If primary or close-to-primary ${ }^{87} \mathrm{Sr} /{ }^{86} \mathrm{Sr}$ is preserved in these marine limestones, a depositional age may be estimated from comparison with the global seawater Sr isotope curve which is now reasonably welldefined to about $900 \mathrm{Ma}$ (Halverson et al. 2007; Sawaki et al. 2010). In a Rb-Sr isochron diagram (Figure 17a), the Bhima Group carbonate data plot in an arc from 0.7064 to 0.7115 . Given their low $\mathrm{Rb} / \mathrm{Sr}$, this wide isotopic range in the carbonate fractions cannot result from in situ $\mathrm{Rb}$ decay. It is more likely to reflect variable isotopic exchange with radiogenic basinal or surficial fluids, or a laboratory artefact (extraction of radiogenic $\mathrm{Sr}$ from residual clay during acid leaching of the limestones). The lowest ${ }^{87} \mathrm{Sr} /{ }^{86} \mathrm{Sr}$ ratios of this data set, $0.7064-0.7070$, are associated with the lowest $\mathrm{Rb} / \mathrm{Sr}$ and high $\mathrm{Sr} / \mathrm{Ca}$ and are therefore possibly primary. The marine $\mathrm{Sr}$ isotope record shows similar ${ }^{87} \mathrm{Sr} /{ }^{86} \mathrm{Sr}$ ratios in the age range $790-870$ Ma (Figure 17b).

\subsection{Rb-Sr ages of Bhima Group glauconites}


The $\mathrm{Rb}-\mathrm{Sr}$ isotope compositions in four glauconite residues and corresponding leachates from EHV956 (Rabanapalli Fm, near the base of the Bhima Group) form two contrasting clusters (residues: ${ }^{87} \mathrm{Rb} /{ }^{86} \mathrm{Sr} \quad 28.8-31.6,{ }^{87} \mathrm{Sr} /{ }^{86} \mathrm{Sr}$ 1.0414-1.0738; leachates: $0.187-0.308,0.7163-0.7173$, Table 3) which are colinear on the $\mathrm{Rb}-\mathrm{Sr}$ isochron diagram and form an 8-point age of 797.4 $\pm 2.6 \mathrm{Ma}$ (MSWD 28, $0.7141 \pm$ 0.0003, Figure 18). Individual residue-leachate 2-point ages vary from $794 \pm 3.9$ to $799 \pm 3.9$ Ma. Residue-leachate pairs from sample EHV957 show greater dispersion and slightly older Rb-Sr ages: the two individual 2-point ages are 810.7 \pm 4.0 and $813.0 \pm 4.0 \mathrm{Ma}$, and the 4 point age is $811.9 \pm 2.8 \mathrm{Ma}$ (MSWD 0.52, $0.70882 \pm 0.00052$, Figure 18). The leachates have ${ }^{87} \mathrm{Sr} /{ }^{86} \mathrm{Sr}$ ratios $(0.716-0.717$ and ca. 0.712) that are substantially higher than ${ }^{87} \mathrm{Sr} /{ }^{86} \mathrm{Sr}$ in ca. $800 \mathrm{Ma}$ seawater $(\sim 0.7065)$, either because the carbonate fractions have a non-marine Sr component, or because of isotopic exchange with the glauconite or other carriers of radiogenic $\mathrm{Sr}$ after sandstone diagenesis or in the laboratory. Recalculation of the glauconite residue $\mathrm{Rb}-\mathrm{Sr}$ ages with an intial ${ }^{87} \mathrm{Sr}{ }^{86} \mathrm{Sr}$ of 0.7065 would increase ages by ca. 20 Ma or less.

\section{DISCUSSION}

\subsection{Discordant detrital zircons}

All zircon populations analysed here are characterized by high proportions of discordant to strongly discordant $\mathrm{U}-\mathrm{Pb}$ isotope compositions. This is unusual because the physical transport involved in producing sandstones would be expected 
to favour the most robust (least radiation-damaged) grains. These in turn should tend to preserve concordant $\mathrm{U}-\mathrm{Pb}$ compositions, as observed in modern beach sands (e.g. Sircombe, 1999) and older sandstones (e.g. Cawood et al. 2000; Kosler et al. 2002). However, high proportions of discordant ages were reported from some Archaean and Mesoproterozoic sandstones (e.g. Cross and Crispe, 2007; Griffin et al. 2004). Discordance in the detrital populations discussed here tends to map out discordia arrays reflecting prominent near-zero-age $\mathrm{Pb}$ loss in all analysed samples, including the in-situ basement granite sample. Discordance may therefore largely reflect post-depositional radiation damage. An additional factor could be the immature nature of the arenitic sandstones of the Kaladgi, Badami and Bhima Groups which may have limited the effect of transport sorting on the quality of the detrital zircon grains. In order to remove such damaged grains, only the concordant analyses are used and discussed herein. Such rigorous data filtering provides clearer insights into the primary zircon crystallization ages and thus provenance of the detrital zircon populations.

\subsubsection{Kaladgi basin detrital zircons}

The Kaladgi basin detrital zircon ages, from one sandstone at the base of the Kaladgi Group and from three sandstones from the base of the Badami Group, record very similar age components. The most prominent is a peak at ca. $2.6 \mathrm{Ga}$ (Figure 11), with secondary peaks at ca. $2.3 \mathrm{Ga}$, which include the youngest detrital zircons (2.2-2.3 Ga) measured in each sample. The third component is represented 
by small but persistent older Archaean age populations (ca. 2.8, 3.3, 3.5, and possibly $4.0 \mathrm{Ga})$.

Paleocurrent directions determined for the lower Kaladgi basin succession indicate $\mathrm{N}$ - to NW-directed transport. This changed to a strongly SW direction during the lower Kerur Formation and to tidal bimodal paleocurrent (NE- and SW-directed) system in the upper part of the Badami Group (Figures 2, 4 and 6). Kaladgi and Badami Group sandstones carry clasts of inferred Archaean gneisses and greenstones, implying they represent immature sediment derived from an Archaean source to the SE or SW of the basin. The most probable source is the west Dharwar craton (WDC), which contains Paleoarchaean greenstones (Sargur Group, Chadwick et al. 2000; Jayananda et al. 2008) and extensive Neoarchaean granites (e.g. the ca. 2.6 Ga Chikmagalur and Chitradurga magmatic events, Chadwick et al. 2007) and may thus be the source of the older detrital zircon age components (see also Sarma et al. 2012). In addition to ca. $3.35 \mathrm{Ga}$ greenstones documented by Jayananda et al. (2008), U-Pb ages for detrital and inherited zircons extracted from the greenstone sequences themselves demonstrate the former existence within the WDC of Archaean age crust as old as $3.6 \mathrm{Ga}$ (Guitreau et al. 2017; Nutman et al, 1992; Sarma et al. 2012), possibly explaining the old Archaean zircon ages in the Kaladagi and Badami group sandstones. However, ages $>3.6 \mathrm{Ga}$, as observed in two of the Kaladgi basin sandstones, have not previously been reported from the WDC and may extend the crustal history of the WDC to the early Eoarchaean.

\subsubsection{Bhima basin detrital zircons}


Three sandstones from the base of the Bhima Group are dominated by a single population at ca. $2.5 \mathrm{Ga}(2.4-2.55 \mathrm{Ga})$, with a slightly older component ( 2.6 Ga) in two of the samples. The youngest ages are between 2.2 and $2.3 \mathrm{Ga}$ in age. Ages $>2.6 \mathrm{Ga}$, of the type seen in the Kaladgi basin sandstones, appear to be absent in the Bhima basin sandstones (Figure 12). The strong $\sim 2.5 \mathrm{Ga}$ age peak suggests a provenance link with the Eastern Dharwar craton (EDC), which is dominated by 2.72.5 Ga greenstone belts (e.g. Dandur, Ramagiri, Kolar-Kadiri, Jayananda et al. 2013) and the ca. $2.5 \mathrm{Ga}$ Closepet Granite which is thought to signal the amalgamation of the EDC and WDC. A link to local EDC basement is also indicated by the similarity of the detrital ages to zircon ages (2540-2650 Ma) for basement granite samples collected near the basin margin; these ages are comparable to those of Neoarchaean granites and gneisses in the EDC (Chadwick et al. 2000). However, the paleocurrent provenance towards NW is difficult to reconcile as the Deccan basalt cover obscures the potential source region for the Bhima Group clastics.

\subsection{The mafic dyke U-Pb baddeleyite age for Kaladgi basin evolution}

The most precise and robust age constraint for the Kaldagi basin is provided by the baddeleyite $\mathrm{U}-\mathrm{Pb}$ age for a dolerite dyke which cuts Hebbal argillite in the Yendigere Formation, at the top of the Lokapur Subgroup, and thus provides a minimum depositional age for the Yendigere Formation, as well as a maximum age for the younger parts of the stratigraphy. The $1861 \pm 4 \mathrm{Ma}$ age for this dolerite dyke is within error of an age for mafic sills within the Tadpatri Formation (Chitravati Group) in the Cuddapah basin, southern India (Anand et al. 2003). Sediment deposition in the 
Cuddapah basin commenced with the ca. 1.9 Ga Papagni Group (Saha et al. 2016; cf. Sahoo et al. 2017). We propose that the lower part of the Kaladgi Group sedimentation is age-equivalent with the Papagni Group and that both represent the earliest stages of Purana basin development in southern India.

\subsection{0ther age constraints}

Bulk digests of multiple specimens of impure limestone EHV679 from the Katageri Limestone, at the top of the Badami Group, define scattered arrays with apparent ages near $960 \mathrm{Ma}$ in ${ }^{238} \mathrm{U} /{ }^{206} \mathrm{~Pb}$ and ${ }^{235} \mathrm{U} /{ }^{207} \mathrm{~Pb}$ isochron plots.

The Shahabad and Katamdevarahalli Limestones of the Bhima Group are the volumetrically dominant units of the Bhima Group, and Kale et al. (1990) proposed these limestones may simply be local variations of a single unit. The Th- $\mathrm{Pb}$ data for all 16 samples (thirteen from the older Shahabad Limestone and three from the younger Katamdevarahalli Limestone) define a common (although scattered) linear array with an apparent age of $910 \pm 130 \mathrm{Ma}$ (Figure 16). The significance of this age is unclear although it is supported by $700-800$ Ma apparent ages derived from comparison of the least radiogenic $\mathrm{Sr}$ isotope compositions for these samples with the marine $\mathrm{Sr}$ isotope curve (Figure 17). Similar ages (ca. $800 \mathrm{Ma}$ ) ages were obtained from $\mathrm{Rb}-\mathrm{Sr}$ dating of diagenetic glauconites in the Rabanapalli Formation at the base of the Bhima Group (Figure 18). Taken together, these results indicate a 
reasonably consistent Neoproterozoic age for the Bhima Group, with the glauconite ages (790-813 Ma) providing the most precise age estimates.

Considering the converging lines of evidences, the Bhima basin is much younger than much of the nearby Kaladgi basin, despite very similar maximum age constraints from the youngest detrital zircon ages in basal sandstones of both basins. The apparent ca. $960 \mathrm{Ma} \mathrm{U}-\mathrm{Pb}$ age for the limestone at the top of the Badami Group may represent a tantalizing hint that the upper part of the Kaladgi basin may be much younger than the lower part dated by the 1862 Ma dolerite. This result also agree with the proposed 900-800 Ma depositional age of the Badami Group through the dating the mafic intrusion which is interpreted to be predating the deposition (Pillai et al. 2018). Further age data are clearly needed to better constrain the age structure of the upper Kaladgi basin.

The similarity of the Badami and Bhima Group carbonates are also supported by Sathyanarayan et al. (1987) with reported similar enrichment in heavy carbon $\delta^{13} \mathrm{C}=$ $3.4 \pm 0.5 \%$ in Badami and Bhima carbonates compared to the $\delta^{13} \mathrm{C}=0.3 \pm 1.2 \%$ for the Kaladgi Group carbonates.

\subsection{Other Purana basins and supercontinents}

Among the Purana basins, the largest preserved, the Cuddapah basin, records the most prolonged and continuous sedimentation and stratigraphic development since 1900 Ma. The age of the dolerite dyke intruding the Yendigere Formation confirms the synchronicity of the development of the lower part of the Kaladgi basin with the 
Cuddapah basin. This extensive passive margin sedimentation occurred prior to the assembly of supercontinent Columbia/Nuna (Saha et al. 2016).

The basin formation and sedimentation in the PG Valley and Chhattisgarh basins developed later in the Mesoproterozoic ( $1600 \mathrm{Ma})$ and continued intermittently to Neoproterozoic times (Saha et al. 2016). Amalgamation of Peninsular India with the formation of the Rodinia supercontinent towards the end of the Mesoproterozoic is evidenced in the PG Valley and Chhattisgarh basin areas (Joy et al. 2018; Merdith et al. 2017).

Based on our new ages, we propose the formation of the Badami-Bhima (and part of Kurnool) basins (800-900 Ma) is linked to the break-up of Rodinia. The extensive carbonate platform development (in Badami, Bhima and Kurnool groups) suggest a Neoproterozoic epeiric sea encircling the northern margin of the Dharwar craton.

\section{CONCLUSIONS}

The data presented here imply that sediment deposition in the Kaladgi basin started at ca. $1.9 \mathrm{Ga}$ and thus at about the same time as in the much larger Cuddapah basin some $250 \mathrm{~km}$ to the southeast. Furthermore, mafic mantle-derived magmatism (dolerite dyke intruding the Yendigere Formation) in the lower Kaladgi basin is very similar in age to mafic sills within the Tadipatri Formation in the Cuddapah basin. Based on these lines of evidence, we propose that the Badami and Bhima Groups are time equivalents deposited at 800-900 Ma. The two depositional cycles, as 
represented by the Kaladgi Group and the Badami Group, were separated by a large time gap of 900-1000 Myr (i.e., an angular unconformity).

A prolonged interruption in sedimentation and the occurrence of a regional unconformity above the Mesoproterozoic sediments is reported from most Purana basins in Southern India (Valdiya, 2016). The Kaladgi Group sediments show intense local deformation prior to the deposition of the Badami Group, which is undeformed and flat-lying.

The zircon provenance for the clastic rocks of Kaladgi basin and the Bhima basin are different, with the Kaladgi basin having zircon input from Paleoarchaean sources plus an early Paleoproterozoic component. The existence of Paleoarchaean crust within the Western Dharwar craton, with crustal growth events at $\sim 3.5 \mathrm{Ga}, \sim 3.3 \mathrm{Ga}$, and $\sim 3.1 \mathrm{Ga}$, is suggested by the detrital zircon record of the Kaladgi Group. The paleoflow direction changed from dominantly towards the NW-N during deposition of the Kaladgi Group to SW directed flow, and finally to strong bimodality (NE-SW) indicating tidal activity during deposition of the Badami Group. In contrast, the Bhima Group clastic sediments show a strong paleocurrent direction towards NE and SE. A strong Paleoproterozoic provenance component is evident in the Bhima basin clastic sediments. The youngest zircons $(2 \cdot 2-2.3 \mathrm{Ga})$ that were recovered from both the Bhima and Kaladgi basins possibly indicate tectonothermal events that immediately predated opening of the Purana basins in southern India. 
We propose, based on our new age results that the Bhima basin and the Badami sedimentation started as a consequence of an extensional tectonic regime probably linked to the initiation of Rodinia supercontinent breakup. This extensional tectonic regime was predated by significant kimberlite and lamproite magmatic activity across southern India and globally at ca. 1.2-1.0 Ga (Tappe et al. 2018a,b), and we suggest that the relatively good preservation of these economically important rock types in India is largely owing to burial within the cratonic Purana basins during several prolonged Proterozoic sedimentation cycles.

\section{ACKNOWLEDGEMENTS}

We thank Professor M. Santosh for inviting us to contribute to this landmark special edition of the Geological Journal. Two anonymous reviewers are thanked for valuable comments and suggestions that helped us too improve this manuscript. This work was funded by De Beers Exploration as part of a joint research project with the Geological Studies Unit, Indian Statistical Institute, Calcutta. We thankfully acknowledge Charles Skinner (Head of Exploration, De Beers) for permission to publish the data and results. ST acknowledge Research on Deep \& Early Earth Processes at the University of Johannesburg which is supported by the DST-NRF CIMERA Center of Excellence, South Africa.

\section{REFERENCES}


Absar, N., Nizamudheen, B.M., Augustine, S. (2016). Petrography, clay mineralogy and geochemistry of clastic sediments of Proterozoic Bhima Group, eastern Dharwar craton, India: implications for provenance and tectonic setting. Journal of Applied Geochemistry, 18, 237-250.

Acharyya, S.K. (2003). A plate tectonic model for Proterozoic crustal evolution of Central Indian Tectonic Zone. Gondwana Geological Magazine, 7, 9-31.

Anand, M., Gibson, S.A., Subbarao, K.V., Kelley, S.P., Dickin, A.P. (2003). Early Proterozoic melt generation processes beneath the intracratonic Cuddapah Basin, Southern India. Journal of Petrology 44, 2139-2171.

Augustine, S., Nizamudheen, B. M., Absar, N., Managave, S., Bhutani, R. (2015). Carbon and Oxygen isotopic composition of Carbonate formations of Bhima Basin, Eastern Dharwar Craton, Karnataka. Abs. in National Seminar on Recent Developments and challenges in Geochemistry (GEOCHEM-2015), ISAG-Annamalai Univ., pp. 27-28.

Basu, A., Bickford M. E. (2015). An alternate perspective on the opening and closing of the intracratonic Purana Basins in Peninsular India. Journal of the Geological Society of India, 85, 5-25.

Bickford, M.E., Basu, A., Patranabis-Deb, S., Dhang, P.C., Schieber, J. (2011). Depositional history of the Chhattisgarh basin, Central India: constraints from new SHRIMP zircon ages. Journal of Geology, 119, 33-50. 
Cawood, P.A. and Nemchin, A.A. (2000). Provenance record of a rift basin: U/Pb ages of detrital zircons from the Perth Basin, Western Australia. Sedimentary Geology, 134, 209-223

Chadwick, B., Vasudev, V.N., Hegde, G.V. (2000). The Dharwar Craton, southern India, interpreted as the result of late Archaean oblique convergence. Precambrian Research, 99, 91-101.

Chadwick, B., Vasudev, V.N., Hegde, G.V., Nutman, A.P. (2007). Structure and SHRIMP, U/Pb zircon ages of granites adjacent to the Chitradurga schist belt: implications for NeoArchaean convergence in the Dharwar craton, Southern India. Journal of the Geological Society of India, 69, 5-24.

Chafetz, H. S., Reid, A. (2000). Syndepositional shallow-water precipation of glauconitic minerals. Sedimentary Geology, 136 (1-2), 29-42.

Chilingar G. V., Bissell H. J., Wolf K.H. (1967). Diagenesis of carbonate rocks. In: Diagenesis in sediments Larsen G. and Chilingar GV (Eds). Developments in sedimentology (8) Elsevier 179-342.

Cross, A. J., and Crispe, A. J. (2007). SHRIPM U-Pb analysis of detrital zircon: a window to understanding the Paleoproterozoic development of the Tanami Region, northern Australia. Mineralium Deposita, 42 (1-2), 27-50.

Dey, S. (2015). Geological history of the Kaladgi-Badami and Bhima basins, south India: sedimentation in a Proterozoic intracratonic setup. In Mazumder, R. And 
Eriksson, P. G. (ed.). Precambrian Basins of India: Stratigraphic and Tectonic Context. Geological Society of London, Memoir, 43, 283-296.

Dongre, A., Chalapathi Rao, N.V., Kamde, G. (2008). Limestone xenolith in Siddanpalli Kimberlite, Gadwal Granite-Greenstone Terrain, Eastern Dharwar craton, Southern India: remnant of Proterozoic platformal cover sequence of Bhima/ Kurnool age? Journal of Geology, 116, 184-191.

French, J.E., Heaman, L.M., Chacko, T., Srivastava, R.K. (2008). 1891-1883 Ma Southern Bastar- Cuddapah maficigneous events, India: a newly recognized large igneous province. Precambrian Research, 160, 308-322.

Griffin, W.L., Belousova, E.A., Shee, S.R., Peasrson, N.J., O’Reilly, S.Y. (2004). Archaean crustal evolution in the northern Yilgarn Craton: U-Pb and $\mathrm{Hf}$-isotope evidence from detrital zircons. Precambrian Research, 131, 231-282.

Guitreau, M., Mukasa, S.B., Loudin, L., Krishnan, S. (2017). New constraints on the early formation of the western Dharwar Craton (India) from igneous zircon U-Pb and Lu-Hf isotopes. Precambrian Research, 302, 33-49.

Halverson, G.P.,Dudas, F.O., Maloof, A.C., Bowring, S.A. (2007). Evolution of the ${ }^{87} \mathrm{Sr} /{ }^{86} \mathrm{Sr}$ composition of Neoproterozoic seawater. Palaeogeography, Palaeoclimatology, Palaeoecology (Palaeo), 256, 103-129.

Holland, T.H., 1907. Indian empire. Geology. Imperial Gazetteer India, 1, 50-103. 
Jackson, S.E., Pearson, N.J., Griffin, W.L., Belousova, E.A. (2004). The application of laser ablation-inductively coupled plasma-mass spectrometry to in situ $\mathrm{U}-\mathrm{Pb}$ zircon geochronology. Chemical Geology, 211, 47-69.

Jaffey, A., Flynn, K., Glendenin, L., Bentley, W., Essling, A. (1971). Precision measurement of half-lives and specific activities of $235 \mathrm{U}$ and $238 \mathrm{U}$. Physical Review, 4, 889-1906.

Jayananda, M., Kano, T., Peucat, J.J., Capdevila, R. (2008). 3.35 Ga komatiite volcanism in the Western Dharwar Craton, southern India: constraints from $\mathrm{Nd}$ isotopes and whole rock geochemistry. Precambrian Research, 162, 160-179.

Jayananda, M., Peucat, J.-J., Chardon, D., Krishna Rao, B., Fanning, C.M., Corfu, F. (2013). Neoarchaean greenstone volcanism and continental growth, Dharwar craton, Southern India: constraints from SIMS U-Pb zircon geochronology and Nd isotopes. Precambrian Research, 227, 55-76.

Jayaprakash, A.V., Sundaram, V., Hans, S.K., Mishra, R.N. (1987). Geology of Kaladgi- Badami basin, Karnataka. Memoirs of the Geological Society of India, 6, 201-206.

Joy, S., Jelsma, H., Tappe, S., Armstrong, R. (2015). SHRIMP U-Pb zircon provenance of the Sullavai group of Pranhitae Godavari basin and Bairenkonda quartzite of Cuddapah basin, with implications for the Southern Indian Proterozoic tectonic architecture. Journal of Asian Earth Sciences, 111, 827-839. 
Joy, S. van der Linde, G., Choudhury, A. K., Deb, G. K., Tappe, S. (2018). Reassembly of the Dharwar and Bastar cratons at ca. $1 \mathrm{Ga}$ : Evidence from multiple tectonothermal events along the Karimnagar granulite belt and Khamam schist belt, southern India. Journal of Earth System Science, 127: 76. https://doi.org/10.1007/s12040-018-0988-2

Kale, V. (1990). Problem of Purana basins. Memoirs of the Geological Society of India, 18, 77-93, Bangalore.

Kale V.S., Phansalkar V. G. (1991). Purana Basins of Peninsular India: a review. Basin Research, 3, 1-36.

Kamber, B.S., Gladu, A.H. (2009). Comparison of Pb purification by anion-exchnage resins methods and assessment of long-term reproducibility of $\mathrm{Th} / \mathrm{U} / \mathrm{Pb}$ ratio measurements by quadrupole ICP-MS. Geostandards and Geoanalytical Research, 33, 169-181.

Kamber, B.S. Greig, A., Schönberg, R., Collerson, K.D. (2003). A refined solution to Earth's hidden niobium: implications for evolution of continental crust and mode of core formation. Precambrian Research, 126, 289-308.

Kosler, J., Fonneland, H., Sylvester, P., Tubrett, M., Pedersen, R-B. (2002). U-Pb dating of detrital zircons for sediment provenance studies - a comparison of laser ablation ICPMS and SIMS techniques. Chemical Geology, 182, 605-618.

Kumar, B., Das Sharma, S., Shukla, M., Aand Sharma, M. (1999). Chronostratigraphic implication of Carbon and Oxygen isotopic compositions of the 
Proterozoic Bhima carbonates, southern India. Journal Geological Society of India, $53,593-600$.

Ludwig, K.R. (2003). User's manual for Isoplot 3.00: A geochronological toolkit for Microsoft Excel. Berkeley Geochronology Center, Special Publication, 4, pp. 71.

Maas, R., Grew, E.S., Carson, C.J. (2015). Isotopic constraints (Pb, Rb-Sr, Sm-Nd) on the sources of Early Cambrian pegmatites with boron and beryllium minerals in the Larseman Hills, Prydz Bay, Antarctica. The Canadian Mineralogist, 53, 249-272.

Meert, J.G., Pandit, M.K., Pradhan, V.R., Banks, J., Stroud, M., Newstead, B., Gifford, J. (2010). Precambrian crustal evolution of Peninsular India: a 3.0 billion year odyssey. Journal of Asian Earth Sciences, 39, 483-515.

Merdith, A.S., Collins, A. S., Williams, S.E., Pisarvesky, S., Foden, J.D., Archibald, D.B., Blades, M.L, Alessio, B.L., Armistead, S., Plavsa, D., Clark, C., Muller, R.D. (2017). A full plate global reconstruction of the Neoproterozoic. Gondwana Research, 50, 84-134.

Mishra, R.N., Jayaprakash, A.V., Hans, S.K., Sundaram, V. (1987). Bhima group of upper proterozoic - a stratigraphic Puzzle. In: Purana basins of peninsular India (middle to late proterozoic). Memoirs of the Geological Soclety of India, 6, 227-237.

Mondal, M.E.A. (2009). Was Bundelkhand-Aravalli nucleus part of the Ur supercontinent? Current Science, 96, 33-35. 
Mukherjee, A., Bickford, M.E., Hietpas, J., Schieber, J., Basu, A. (2012). Implications of a newly dated ca. 1000-Ma rhyolitic tuff in the Indravati basin, Bastar craton, India. Journal of Geology, 120, 477-485.

Mukhopadhyay, S., Samanta, P., Bhattacharya, S., Sarkar S. (2019). Stratigraphic Evolution and Architecture of the Terrestrial Succession at the Base of the Neoproterozoic Badami Group, Karnataka, India. In: Mondal M. (eds) Geological Evolution of the Precambrian Indian Shield. Society of Earth Scientists Series. Springer, Cham. https://doi.org/10.1007/978-3-319-89698-4_6

Nagarajan, R., Sial, A.N., Armstrong-Altrin, J.S., Madhavaraju, J., Nagendra, R., 2008. Carbon and oxygen isotope geochemistry of Neoproterozoic limestones of the Shahabad Formation, Bhima Basin, Karnataka, Southern India. Revistas Mexicana de Ciencias Geologicas, 25, 225-235.

Nutman, A.P., Chadwick, B., Ramakrishnan, M., Viswanatha, M.N. (1992). SHRIMP U-Pb ages in Sargur Supracrustal rocks in Western Karnataka, Southern India. Journal of the Geological Society of India, 39, 367-374.

Odin, G. S., and Matter, A. (1981). De glauconiarum origine. Sediment, 28, 611-641.

Olsson, J., Söderlund, U., Klausen, M., Ernst, R. (2010). U-Pb baddeleyite ages linking major Archaean dyke swarms to volcanic-rift forming events in the Kaapvaal craton (South Africa), and a precise age for the Bushveld Complex. Precambrian Research, 183, 490-500. 
Padmakumari, V.M., Sambasiva Rao, V.V., Srinivasan, R. (1998). Model Nd and $\mathrm{Rb}-\mathrm{Sr}$ ages of shales of the Bagalkot Group, Kaladgi Supergroup, Karnataka. Abstracts: National Symposium on Late Quaternary Geology and Sea level Changes. Cochin University, Kochi, p. 70.

Pandey, O.P., Agarwal, P.K. (1999). Lithospheric mantle deformation beneath the Indian cratons. Journal of Geology, 107, 683-692.

Patranabis-Deb, S. (2018). Origin and sequences of sedimentary structures of shelf macrotidal sandstone bars in the Neoproterozoic Kerur Formation of the Badami Group, Kaladgi Basin, India. Abstract volume, 31st IAS Meeting of Sedimentology, 22-25 June, 2015, Krakow, Poland www.ing.uj.edu.pl/ims2015. p. 404.

Patranabis-Deb S., Słowakiewicz M., Tucker M.E, Pancost R.D., Bhattacharya P., (2016). Carbonates and related facies with vestiges of biomarkers from the Chattisgarh Basin, India: Clues to redox conditions in the Mesoproterozoic ocean. Gondwana Research, 35:411-424. DOI: 10.1016/j.gr.2015.06.007

Pillai, P. S., Pande, K., Kale, V. S. (2018). Implications of new ${ }^{40} \mathrm{Ar} /{ }^{39} \mathrm{Ar}$ age of Mallapur Intrusives on the chronology and evolution of the Kaladgi basin, Dharwar craton, India. Journal of Earth System Science, 127: 32. https://doi.org/10.1007/s12040-018-0940-5

Radhakrishna, B.P., Naqvi, S.M. (1986), Precambrian continental crust of India and its evolution. Journal of Geology, 94, 145-166. 
Radhakrishna, B.P., Vaidyanadhan, R. (1994). Geology of Karnataka. Geological Society of India, Bangalore.

Raha, P.K., Sastry, M.V.A. (1982). Stromatolites and Precambrian stratigraphy in India. Precambrian Research, 18, 293-318.

Rogers, J.J.W., (1996). A history of the continents in the past three billion years. Journal of Geology, 104, 91-107.

Saha, D., Mazumder, R. (2012). An overview of the Palaeoproterozoic geology of Peninsular India, and key stratigraphic and tectonic issues. In: R. Mazumder, D. Saha (Eds) Palaeoproterozic of India, Geological Societyof London Special Publication, 365, 5-29.

Saha, D., Patranabis-Deb, S. Collins, A. (2016). Proterozoic stratigraphy of Southern India cratons and Global context, Stratigraphy \& Timescales, Volume 1, 1-59, Elsevier Inc. http://dx.doi.org/10.1016/bs.sats.2016.10.003

Sahoo, D. Pruseth, K.L., Upadyay, D., Ranjan, S., Pal, D., Banerjee, R., Gupta, S. (2017). New constraints from zircon, monazite and uraninite dating on the commencement of sedimentation in the Cuddapah basin, India. Geological Magazine, https://doi.org/10.1017/S0016756817000140

Sambasiva Rao, V. V., Sreenivas, B., Balaram, V., Govil, P. K. and Srinivasan, R. (1999). The nature of the Archaean upper crust as revealed by the geochemistry of the Proterozoic shales of the Kaladgi basin, Karnataka, South India. Precambrian Research, 98, 53-65 
Sarma, S.D., McNaughton, N.J., Belusova, E., Mohan, R.M., Fletcher, I.R. (2012). Detrital zircon $\mathrm{U}-\mathrm{Pb}$ ages and Hf-isotope systematics from the Gadag Greenstone Belt: Archaean crustal growth in the western Dharwar Craton, India. Gondwana Research, 22, 843-854.

Sathyanarayan, S., Arneth, J.D., Schidlowski, M. (1987). Stable isotope geochemistry of carbonates from the Proterozoic Kaladgi, Badami and Bhima Groups, Karnataka, India: Precambrian Research, 37, 147-156.

Sawaki, Y., Kawai, T., Shibuya, T., Tahata, M., Omori, S., Komiya, T., Yoshida, N., Hirata, T., Ohno, T., Windley, B.F., Maruyama, S. (2010). 87Sr/86Sr chemostratigraphy of neoproterozoic Dalradian carbonates below the Port Askaig Glaciogenic Formation, Scotland. Precambrian Research, 179, 150-164.

Sharma, M., Pandey, S.K. (2012). Stromatolites of the Kaladgi Basin, Karnataka, India: their systematics, biostratigraphy and age implications. Palaeobotanist, 61, 103-121.

Sircombe, K.N. (1999). Tracing provenance through the isotope ages of littoral and sedimentary detrital zircon, eastern Australia. Sedimentary Geology, 124, 47-67.

Söderlund, U., Johansson, L. (2002). A simple way to extract baddeleyite (ZrO2). Geochemistry Geophysics Geosystems, 3, (https://doi.org/10.1029/2001GC000212) Stacey, J.S., Kramers, J.D. (1975). Approximation of Terrestrial lead isotope evolution by a two-stage model. Earth and Planetary Science Letters, 26, 207-221. 
Tappe, S., Smart, K. A., Torsvik, T. H., Massuyeau, M., and de Wit, M. C. J., (2018a). Geodynamics of kimberlites on a cooling Earth: Clues to plate tectonic evolution and deep volatile cycles: Earth and Planetary Science Letters, v. 484, p. 114.

Tappe, S., Dongre, A., Liu, C.-Z., and Wu, F.-Y., (2018b). 'Premier' evidence for prolonged kimberlite pipe formation and its influence on diamond transport from deep Earth: Geology, v. 46, p. 843-846.

Valdiya, K.S. (2016). The Making of India, Geodynamic Evolution. Springer, Switzerland. P. pp. 923.

Van Achterbergh, E., Ryan, C.G., Jackson, S.E., Griffin, W.L. (2001). LA-ICP-MS in the Earth Sciences - Appendix 3, data reduction software for LA-ICP-MS, in: Sylvester, P.J. (Ed.), Short Course Mineralogical Association of Canada, St.John's, 239-243.

Wignall P. B. (1994). Black shales: Oxford UK, Claredon Press 127p.

Woodhead, J.D. (2002). A simple method for obtaining highly accurate $\mathrm{Pb}$ isotope data by MC-ICP-MS. Journal of Analytical Atomic Spectrometry, 17, 1-6.

Woodhead, J.D., Volker, F., McCulloch, M.T. (1995). Routine lead isotope determinations using a ${ }^{207} \mathrm{~Pb} /{ }^{204} \mathrm{~Pb}$ double spike: a long-term assessment of analytical precision and accuracy. The Analyst, 120, 35-39.

Zhao, G., Sun, M., Wilde, S.A., Li, S. (2004). A Palaeo-Mesoproterozoic supercontinent assembly, growth and breakup. Earth Science Reviews, 67, 91-123. 


\section{FIGURE CAPTIONS}

Figure 1: Location map of the Kaladgi (K), Bhima (B), Cuddapah (C) and PranhitaGodavari (PG) basins with local simplified geology. The inset shows the location of the study area in India.

Figure 2: Stratigraphy, depositional environment and measured paleocurrent patterns of the Kaladgi basin.

Figure 3: Field photographs and petrography, Kaladgi Group and Badami Group. (a) Ramdurg Formation massive conglomerate with clasts of vein quartz, jasper, granite and quartzite. (b) Ramdurg Formation, coarse grained feldspathic sandstone from the lower part of the succession with well-preserved cross strata sets. (c) photomicrograph of very poorly sorted pebbly sandstone (Ramdurg Formation). Quartz grains are closely packed, many with sutured contacts. Pebbles are metaquartzite, chert or quartzite. (d) Wave rippled upper part of the Kerur Formation (cave temple arenite). Note the tuning fork bifurcation of the ripples.

Figure 4: Stratigraphy, depositional environment and measured paleocurrent patterns of Bhima basin.

Figure 5: Field photographs, Bhima Group. a) Rabanpalli Sandstone. Note the coarse-grained sandstone and granule-stone, overlies granitic basement. b) Sharp contact between brown shale of the Halkal Formation and grey flaggy limestone of the Katamdevarahalli Formation. Sharp boundary points to sharp changes in depositional environment. c) Limestone marl rhythmite of the Shahabad Formation. 
d) Shahabad Formation. The arrows point to the marly layers, which separates the flaggy limestone beds. These black limestones are laterally extensive, thus are being used as marker beds for interbasinal correlation.

Figure 6: Paleocurrent direction patterns measured in the Kaladgi (brick red), Badami (yellow) and Bhima sandstones (pink).

Figure 7: Map showing the sample locations and analysis type.

Figure 8: Photomicrographs of sandstone sample EHV956. Panel (a) and (b) provide a textural overview in planar- and cross-polarized light, respectively. Panel (c) displays intergrowth between cement-forming carbonate (Dol) and glauconite (Glt), whereas (d) illustrates incipient replacement of glauconite by carbonate in the matrix between sand-sized quartz grains (Qtz).

Figure 9: Photomicrographs of sandstone-mudstone intercalation with coarsegrained dolomite cement (sample EHV957). Panel (a) and (b) provide a textural overview in planar- and cross-polarized light, respectively. Panel (c) displays the intimate relation between cement-forming glauconite (Glt) and dolomite (Dol). Panel (d) shows two apatite prisms (Ap) that are enclosed by a glauconite pellet indicating an authigenic nature of the glauconite in EHV957. Panel (e) shows a kinked glauconite pellet that is surrounded by secondary limonite (Lm). Panel (f) displays a bedding-parallel stylolite which developed within a clay-rich layer during compaction.

Figure 10: Examples of back scatter electron Z images captured using a Cameca SX100 Electron Probe Micro Analyser. The ablation spots are $35 \mu \mathrm{m}$ in diameter. 
Figure 11: U-Pb age relative probability and concordia diagrams (only $<15 \%$ discordant) of zircon from the Kaladgi basin samples.

Figure 12: $\mathrm{U}-\mathrm{Pb}$ age relative probability and concordia diagrams (only $<15 \%$ discordant) of detrital zircon from the Bhima basin samples.

Figure 13: U-Pb concordia diagrams (all data) of zircon from the basement granite sample.

Figure 14: U-Pb concordia diagram of three fractions of baddeleyite from EHW667. Error ellipses depict 2s errors.

Figure 15: U-Th-Pb isotopic compositions of multiple specimens of limestone (EHV679) from the Katageri Limestone (Badami Group). Data shown are for bulk dissolutions (red) and carbonate fractions (blue). (A) ${ }^{238} \mathrm{U}-{ }^{206} \mathrm{~Pb}$ isochron diagram; data for bulk digestions of EHV679 define an imprecise ca. 0.96 Ga array with a high initial ${ }^{206} \mathrm{~Pb} /{ }^{204} \mathrm{~Pb}$ (24.5). (B) ${ }^{232} \mathrm{Th}-{ }^{208} \mathrm{~Pb}$ isochron diagram.

Figure 16: Th-Pb isotopic compositions in carbonate fractions of Shahabad Limestone (13 samples, red) and Katamdevarahalli Limestone (3 samples, blue). ${ }^{232} \mathrm{Th}-{ }^{208} \mathrm{~Pb}$ isochron diagram showing scattered but consistent linear correlation with an apparent age of $910 \pm 130 \mathrm{Ma}$.

Figure 17: $\mathrm{Rb}-\mathrm{Sr}$ isotopic data for carbonate fractions of Shahabad Limestone (13 samples, red) and Katamdevarahalli Limestone (3 samples, blue). (A) Rb-Sr isochron diagram; steep array defined by samples is well above a 1.9 Ga reference isochron and cannot result from ingrowth since sediment deposition. (B) ${ }^{87} \mathrm{Sr} /{ }^{86} \mathrm{Sr}$ vs 
age showing the samples used to define the Sr isotopic evolution of Neoproterozoic seawater (replotted using data from Halverson et al. 2007). If the lowest ${ }^{87} \mathrm{Sr} /{ }^{86} \mathrm{Sr}$ observed for the Bhima Gp carbonate fractions preserves a depositional marine $\mathrm{Sr}$ isotope signal, it indicates a maximum depositional age of 790-870 Ma.

Figure 18: Rb-Sr isochron diagram for glauconites from Rabanapalli Fm sandstones (Bhima Group). Data shown are for acid leachates (low Rb/Sr) and complementary residues (high $\mathrm{Rb} / \mathrm{Sr}$ ) for 6 separates (4 from EHV956, 2 from EHV957). The data define pooled isochrons in the range 797 to $812 \mathrm{Ma}$.

\section{LIST OF TABLES}

Table 1: Sample location and details.

Table 2: $\mathrm{Pb}-\mathrm{Sr}$ isotopic data for the limestones.

Table 3: Rb-Sr isotope results for glauconite from sandstones EHV956 and EHV957.

\section{ANNEXURES}

Annexure 1: Results of U-Pb LA-ICPMS analysis of GJ1 standard. The sample numbers for which the standard was analysed is given as part of the grain ID.

Annexure 2: U-Pb Concordia diagram for GJ1- combined for all the analysis.

Annexure 3: Results of U-Pb LA-ICPMS analysis of the detrital zircons from (a) EHV678, (b) EHV680, (c) EHV683, (d) EHV689, (e) EHV951, (f) EHV953, (g) EHV 962. Data in red are rejected.

Annexure 4: Results of U-Pb LA-ICPMS analysis of the zircons from EHV954. 


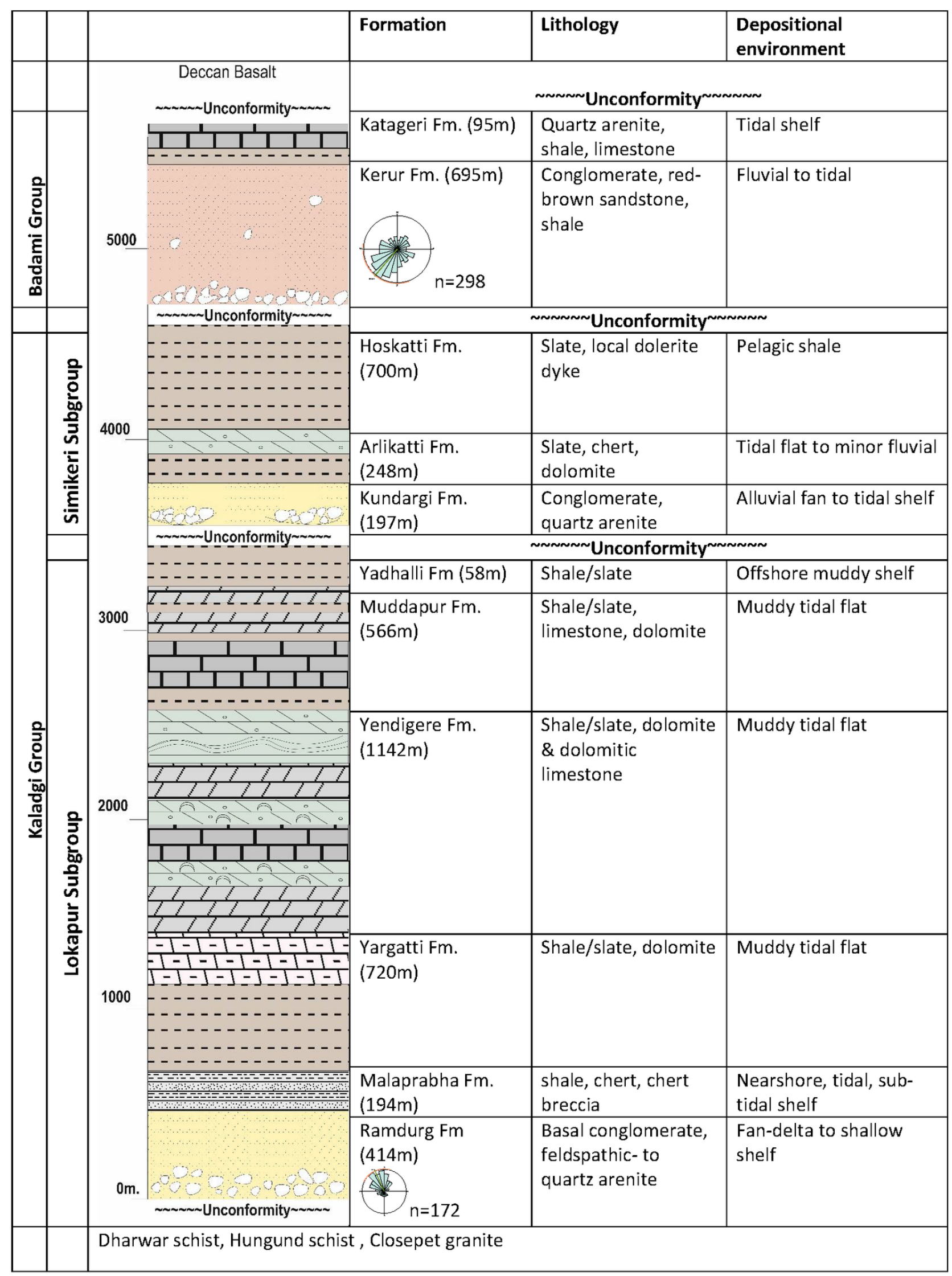

GJ_3415_F2.tiff

This article is protected by copyright. All rights reserved. 

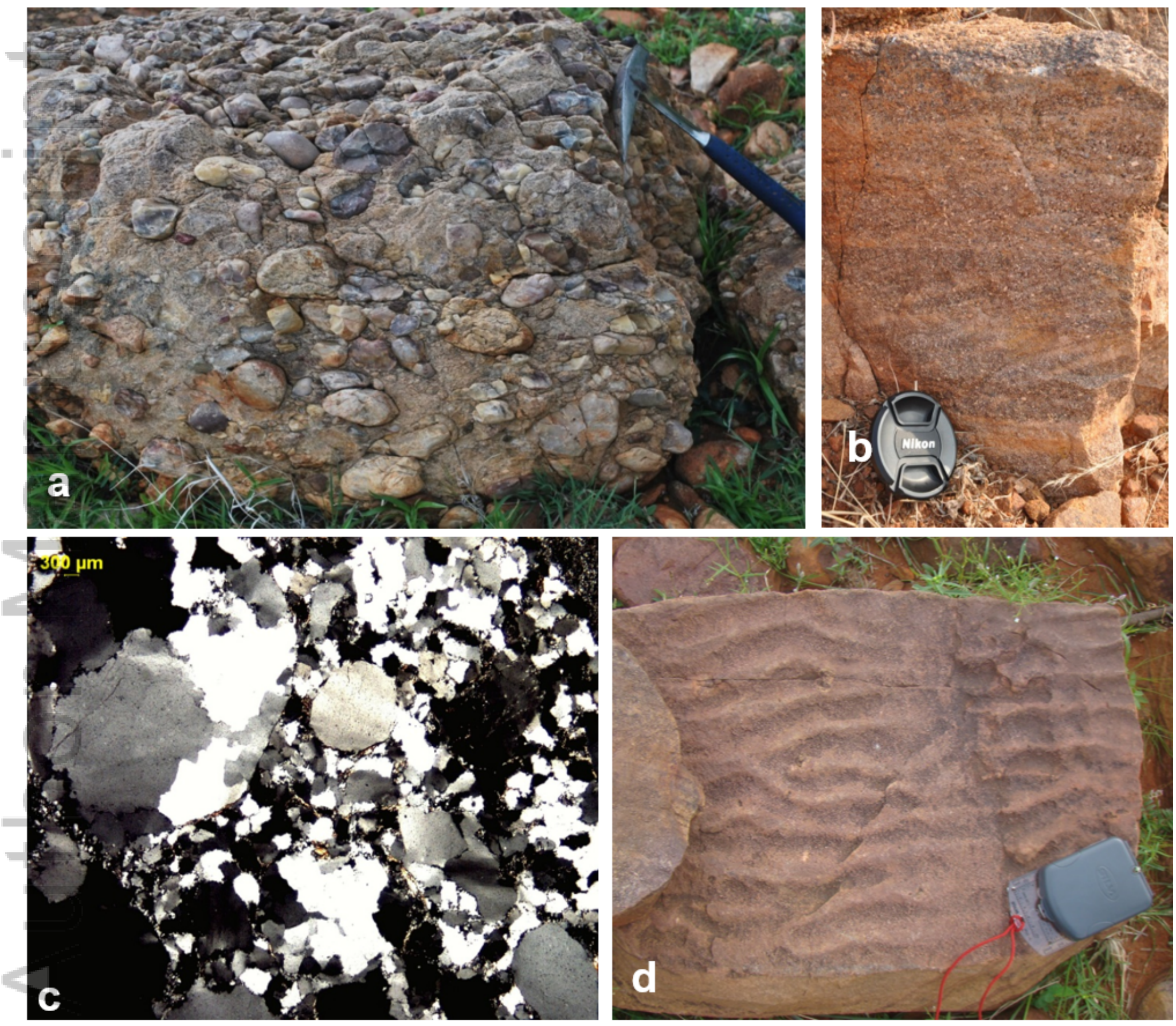

GJ_3415_F3.tif 


\begin{tabular}{|c|c|c|c|c|}
\hline \multirow{11}{*}{ 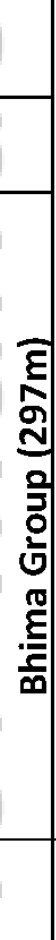 } & \multirow{10}{*}{ Uncontormity } & Formation & Lithology & $\begin{array}{l}\text { Depositional } \\
\text { environment }\end{array}$ \\
\hline & & \multicolumn{3}{|c|}{ Unconformity } \\
\hline & & Harwal Formation $(45 \mathrm{~m})$ & Shale & Offshore muddy shelf \\
\hline & & $\begin{array}{l}\text { Katamdevarahalli } \\
\text { Formation }(40 \mathrm{~m})\end{array}$ & $\begin{array}{l}\text { Flaggy } \\
\text { Limestone }\end{array}$ & Carbonate platform \\
\hline & & Halkal Formation $(30 \mathrm{~m})$ & Shale & Pelagic shale \\
\hline & & Shahabad Limestone & Flaggy & Nonstromatolitic \\
\hline & & & Limestone & carbonate platform \\
\hline & & Rabanpalli Formation & Conglomerate, & Fan-delta to shallow \\
\hline & & & $\begin{array}{l}\text { sandstone, } \\
\text { shale }\end{array}$ & \\
\hline & & & & \\
\hline & $\begin{array}{l}\text { Dharwar schist, Hungund schist, } \\
\text { Closepet granite }\end{array}$ & Dharwar schist, Hungund & ist, Closepet gral & \\
\hline
\end{tabular}

GJ_3415_F4.tif

This article is protected by copyright. All rights reserved. 

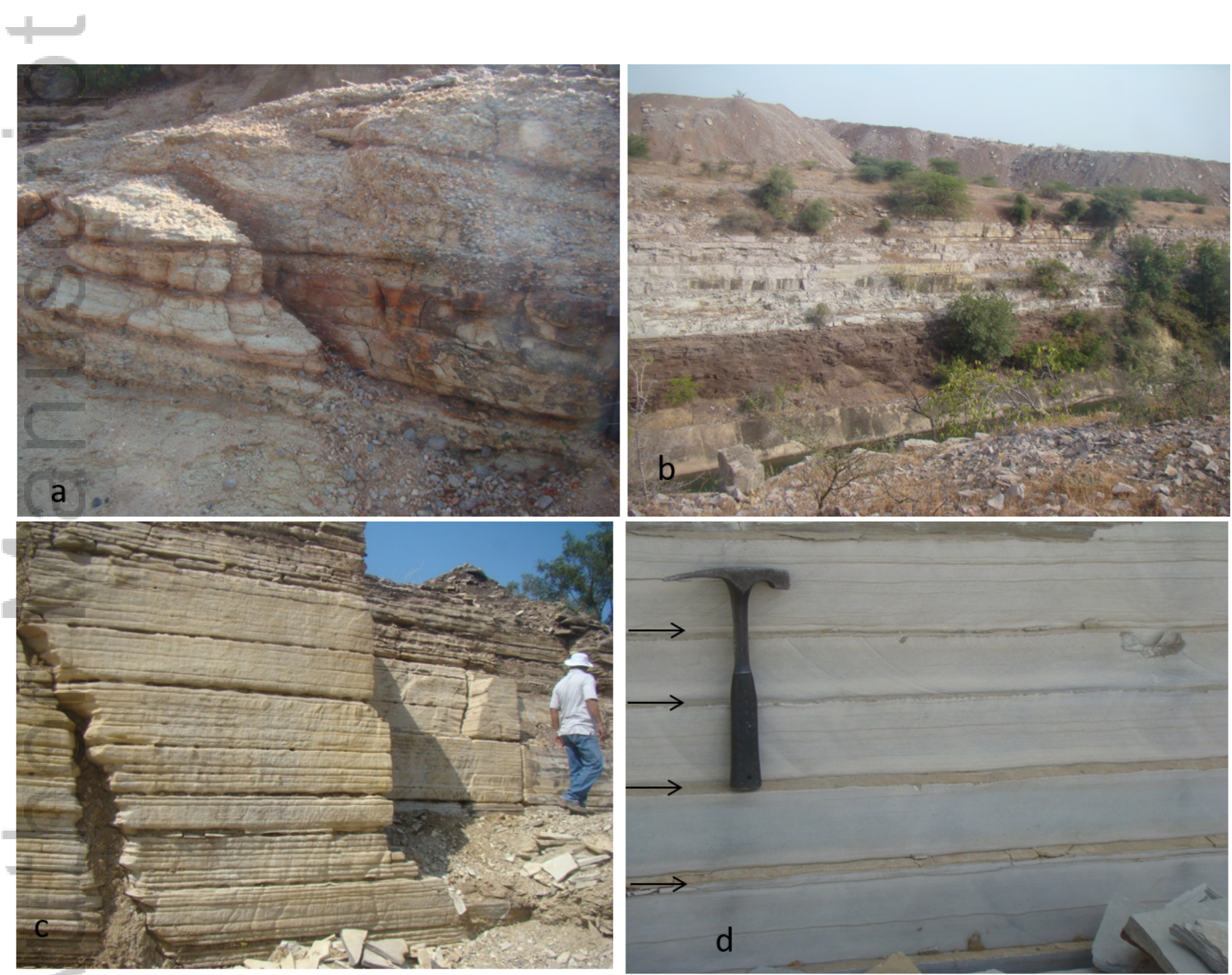

GJ_3415_F5.tif 


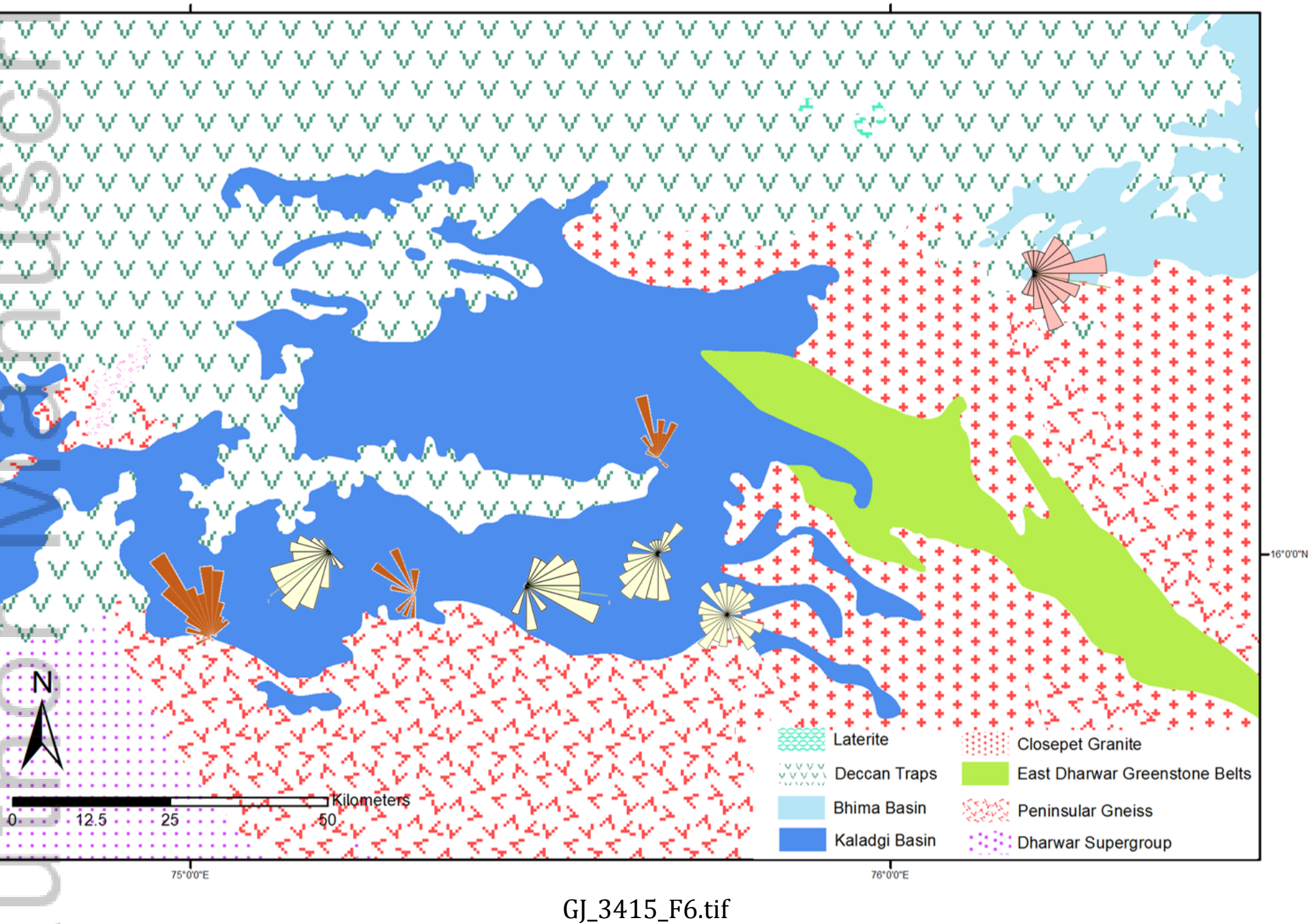

This article is protected by copyright. All rights reserved. 


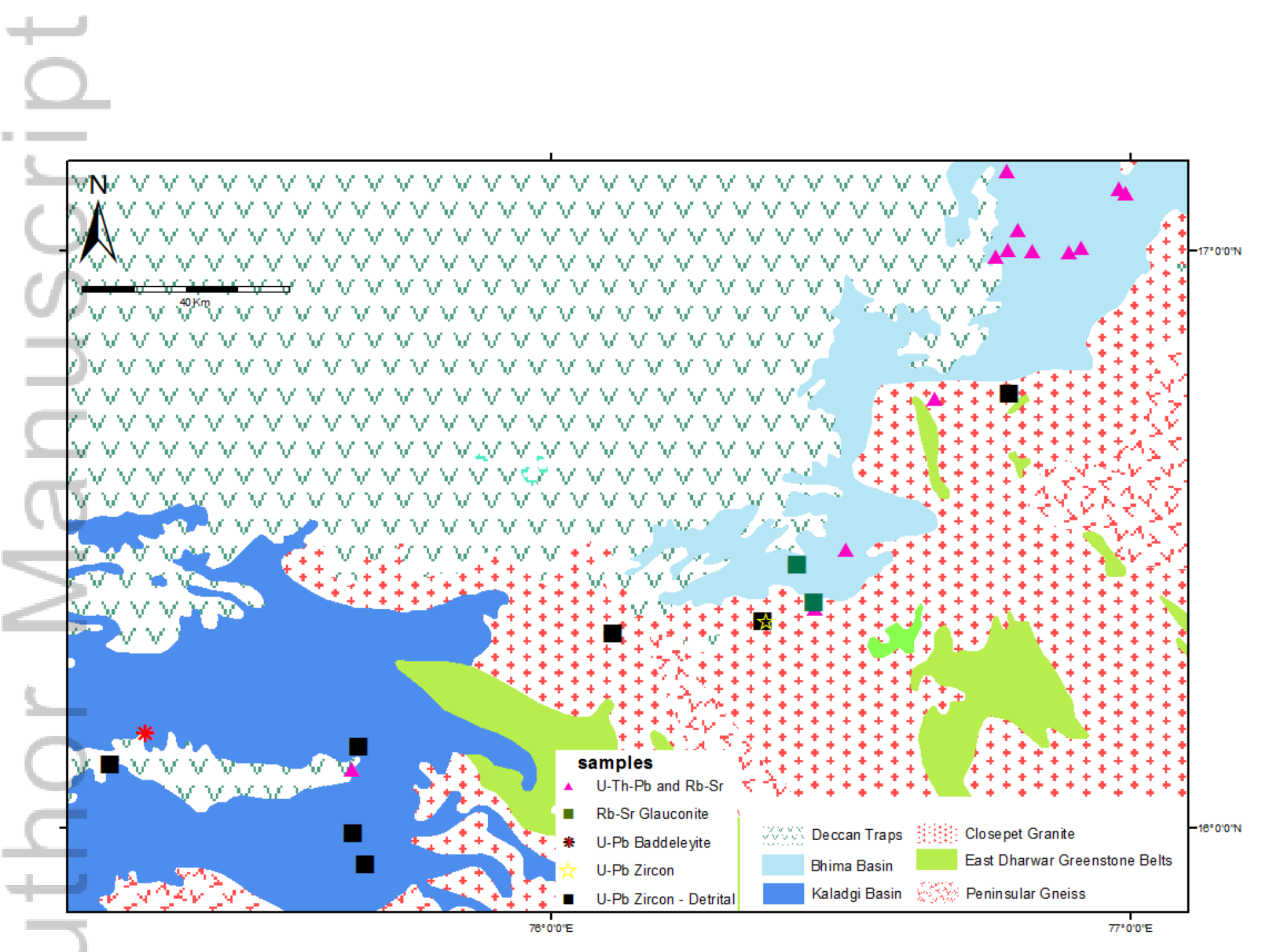

GJ_3415_F7.tif 


\section{EHV956}

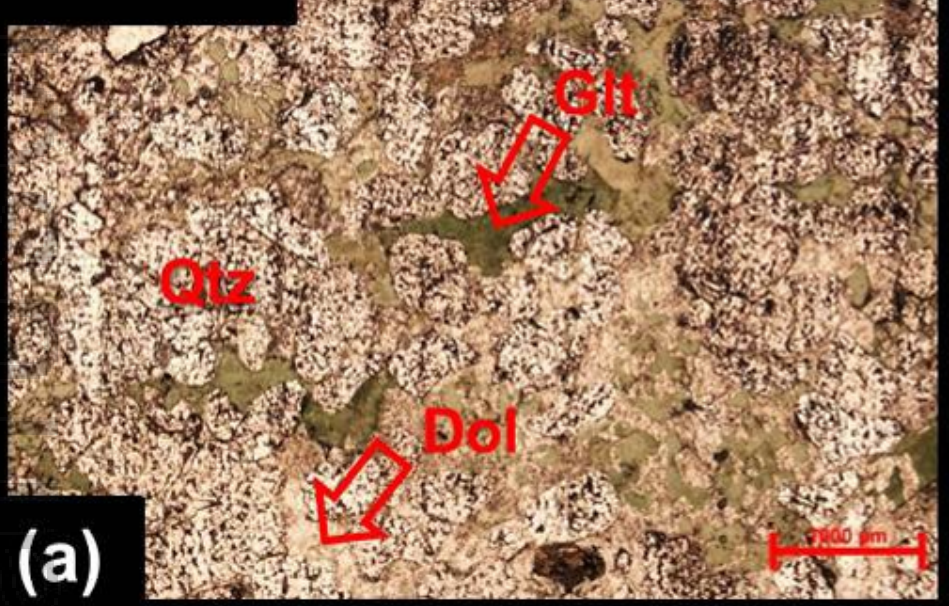

\section{EHV956}

Y. What elt dtet Honts elt Sith

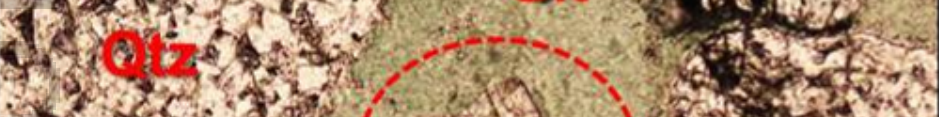

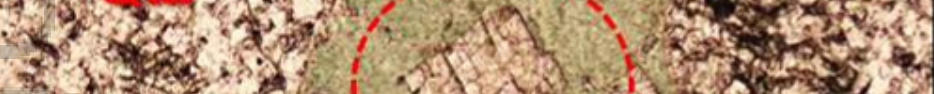
1.

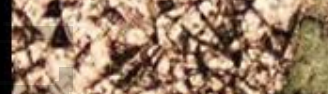

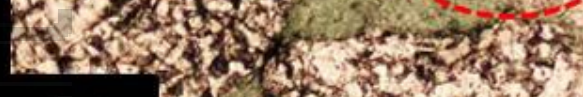

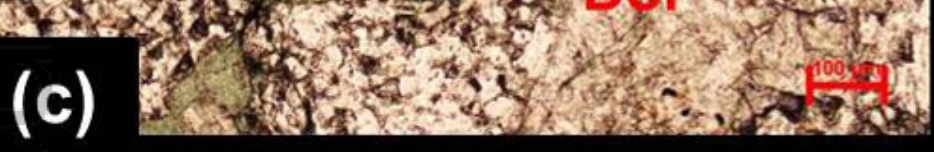
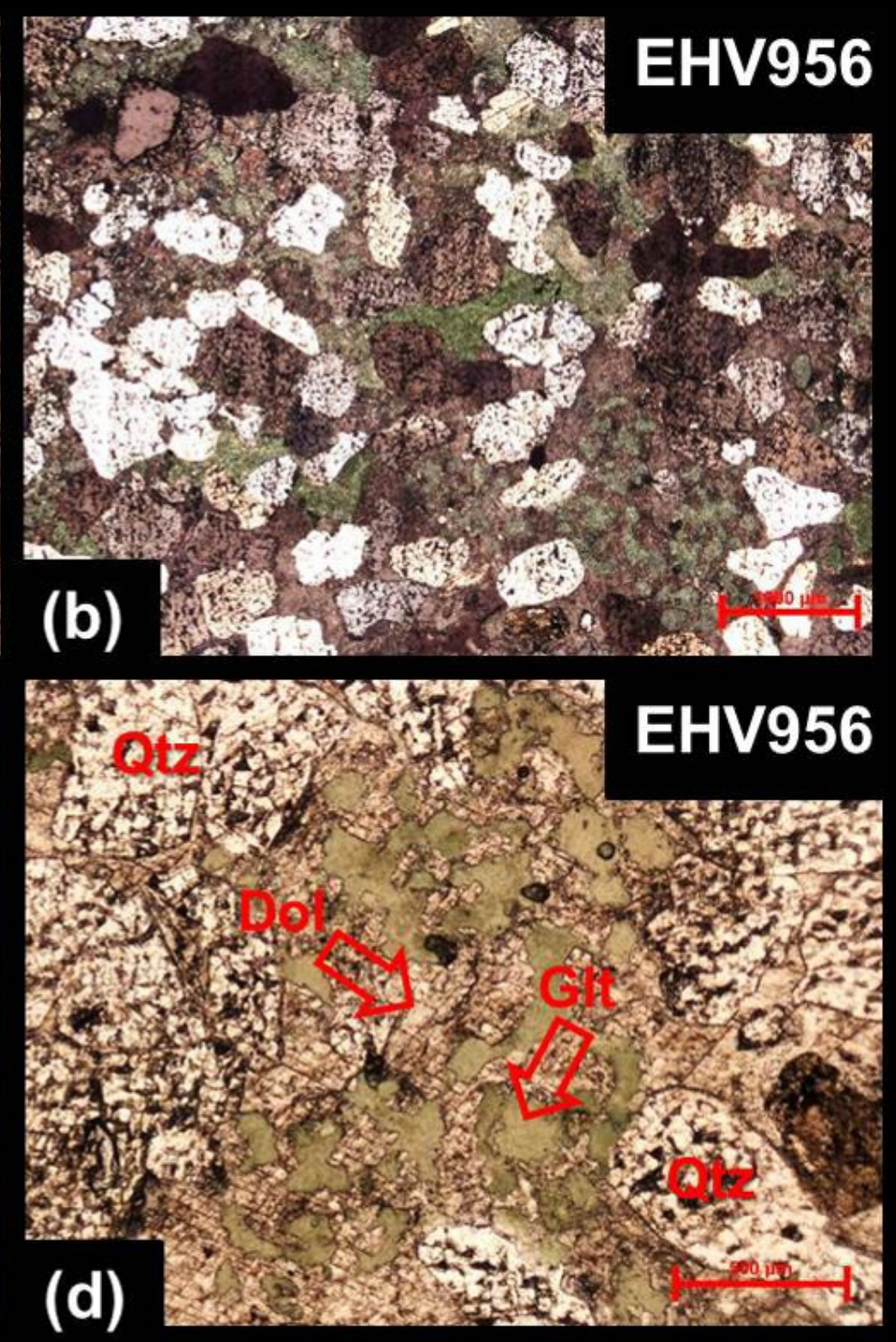

GJ_3415_F8.tif 


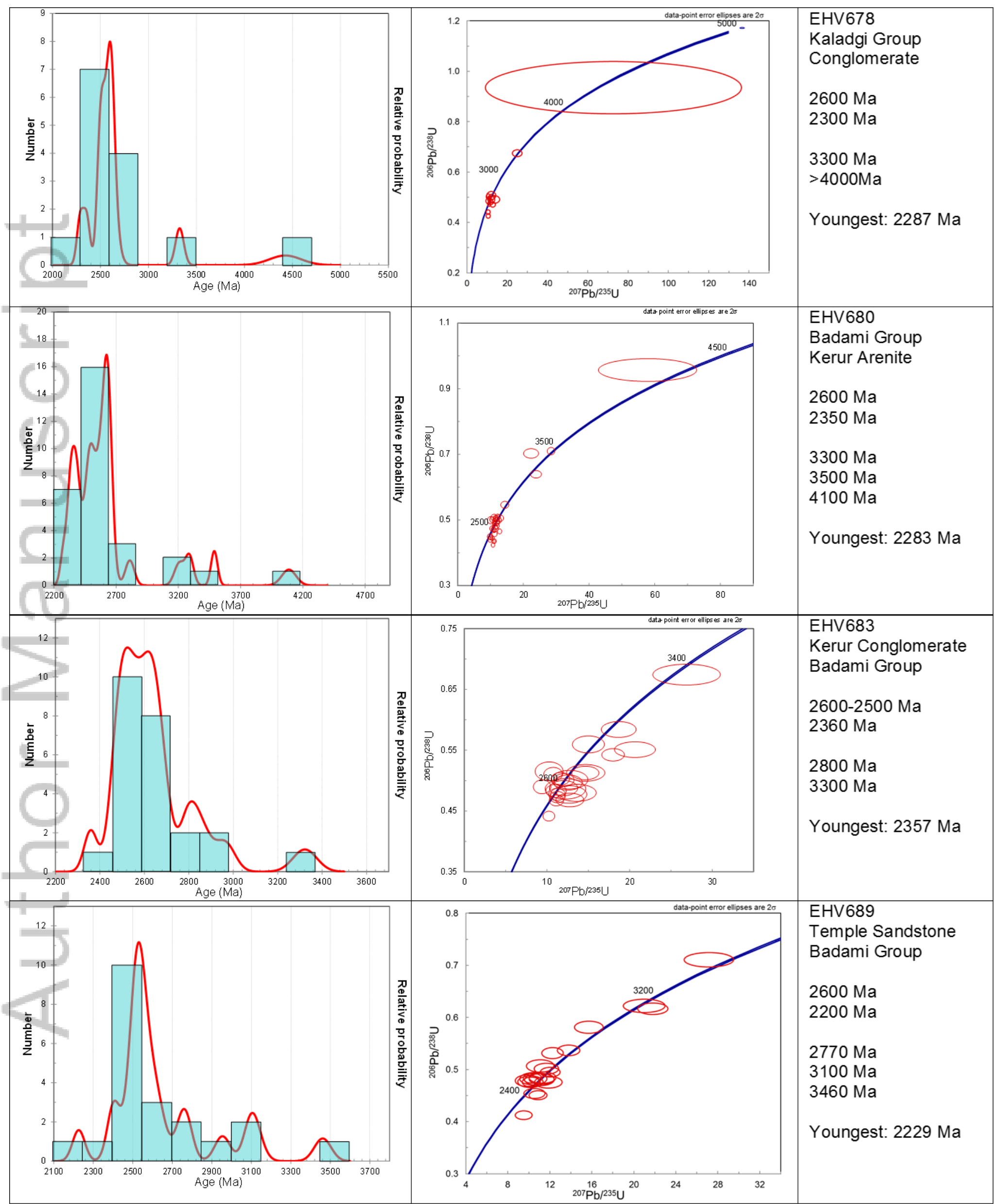




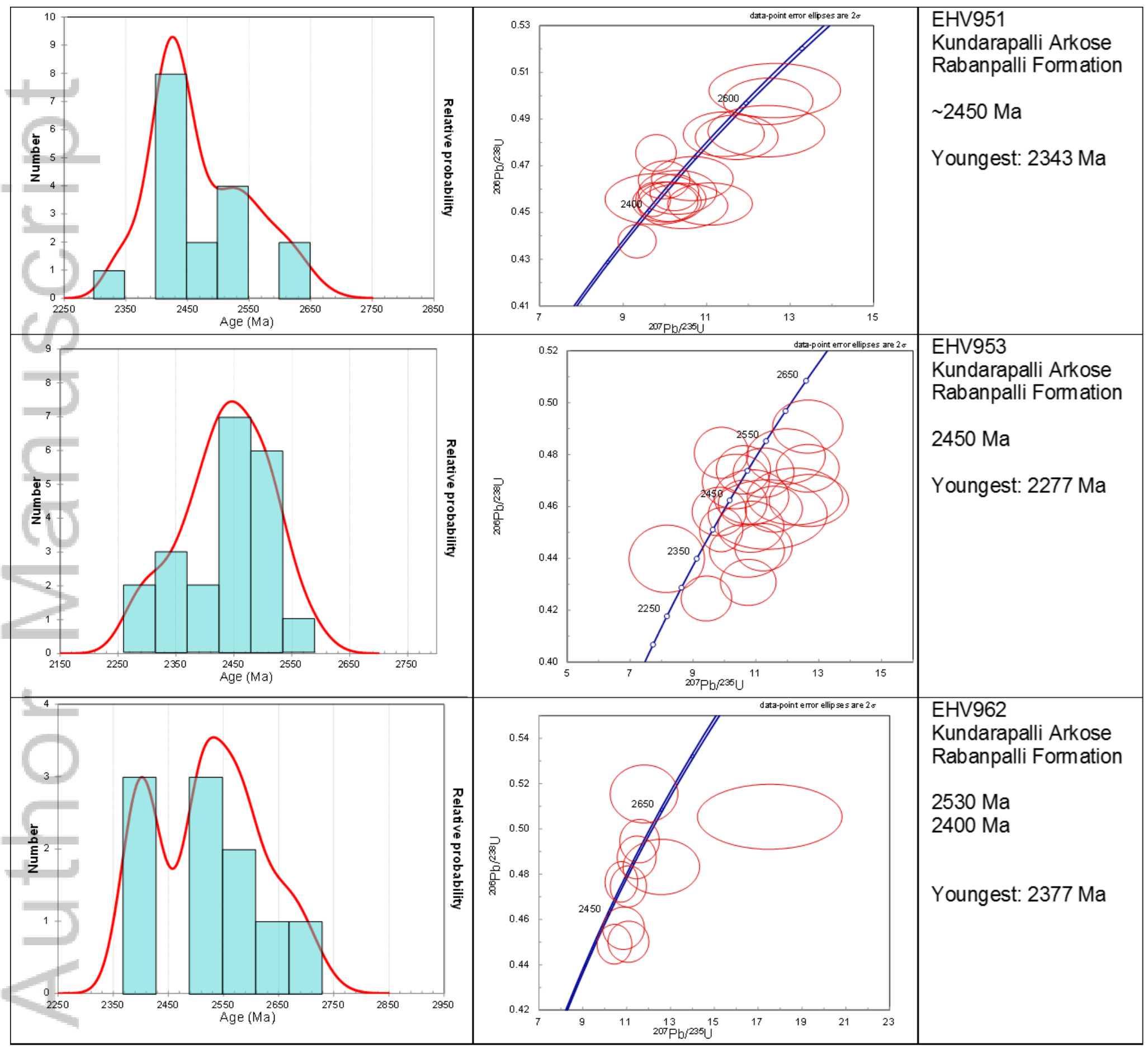

GJ_3415_F12.tif

This article is protected by copyright. All rights reserved. 


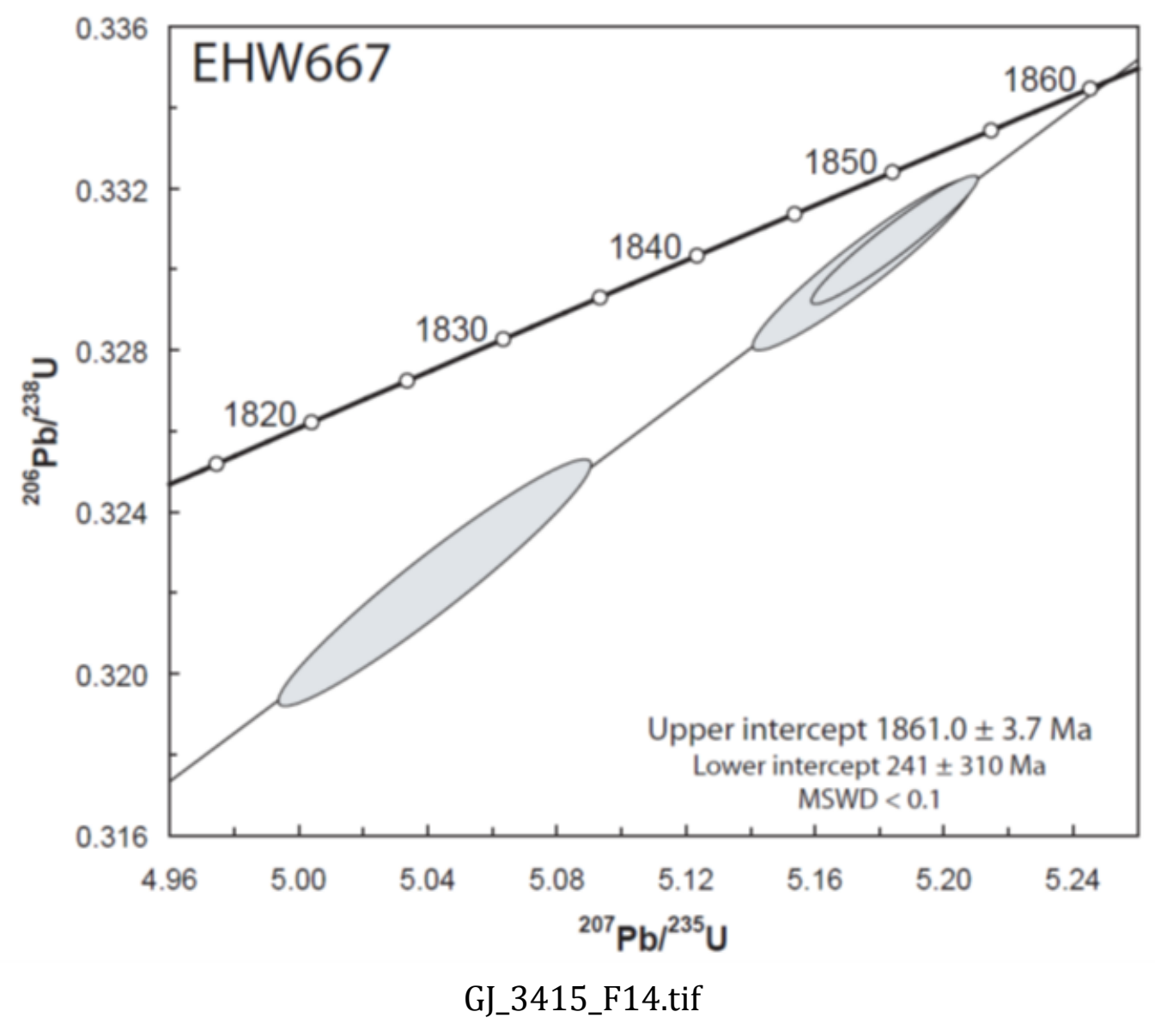

This article is protected by copyright. All rights reserved. 

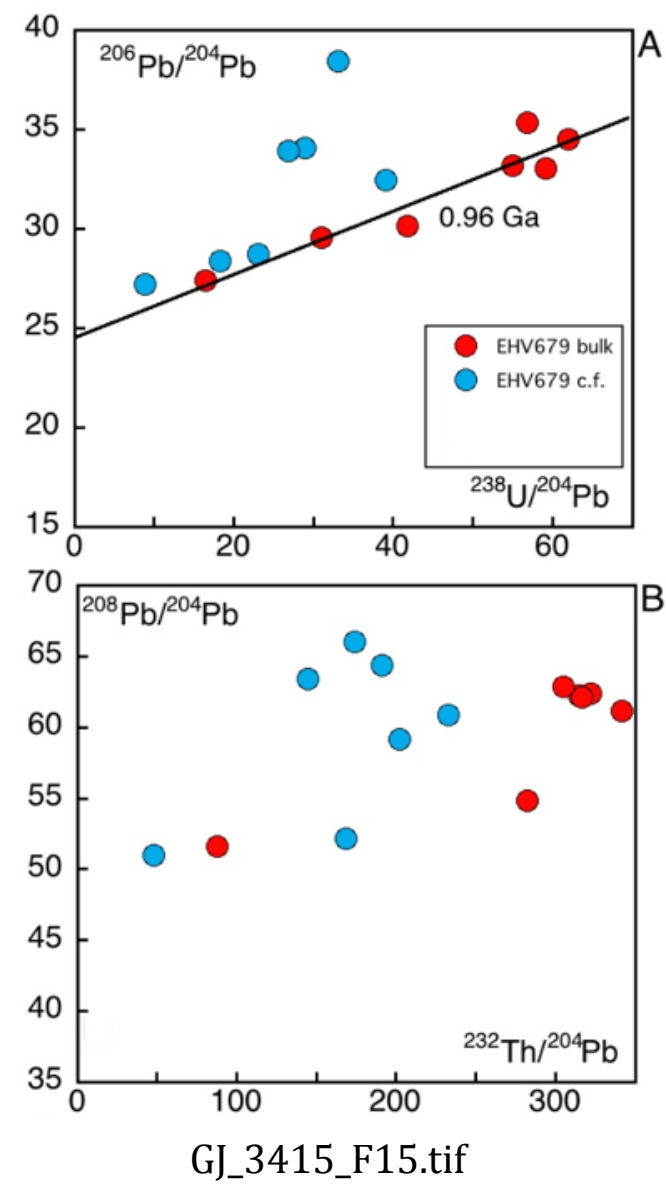

This article is protected by copyright. All rights reserved. 


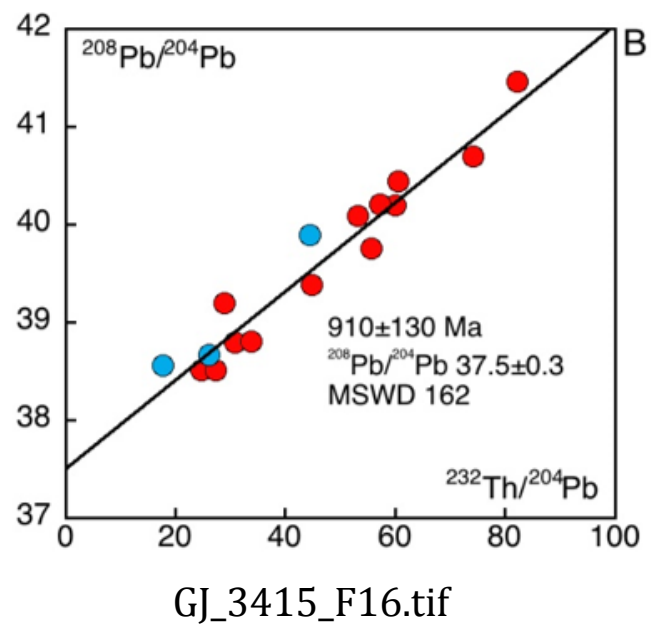

This article is protected by copyright. All rights reserved. 

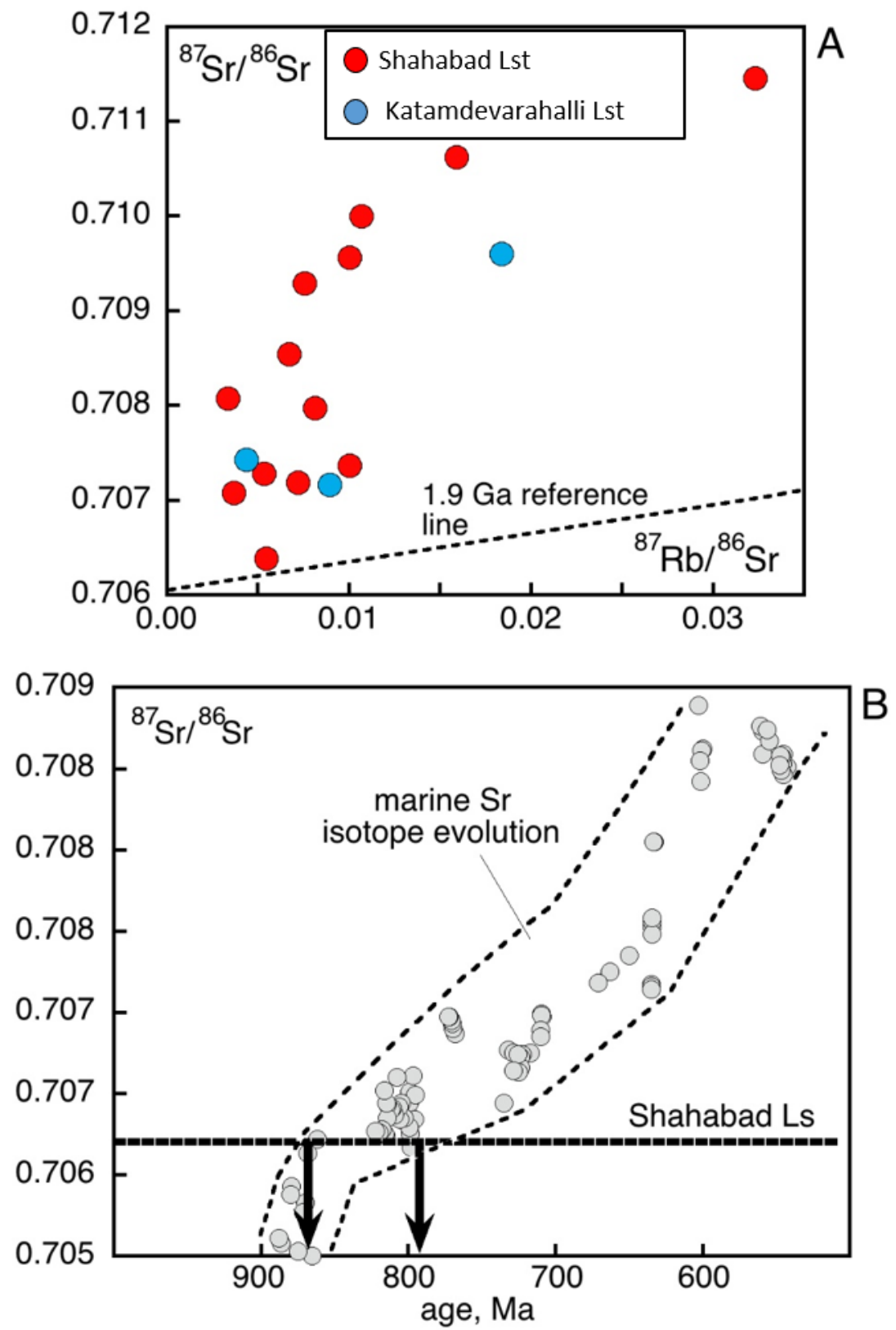

GJ_3415_F17.tif 


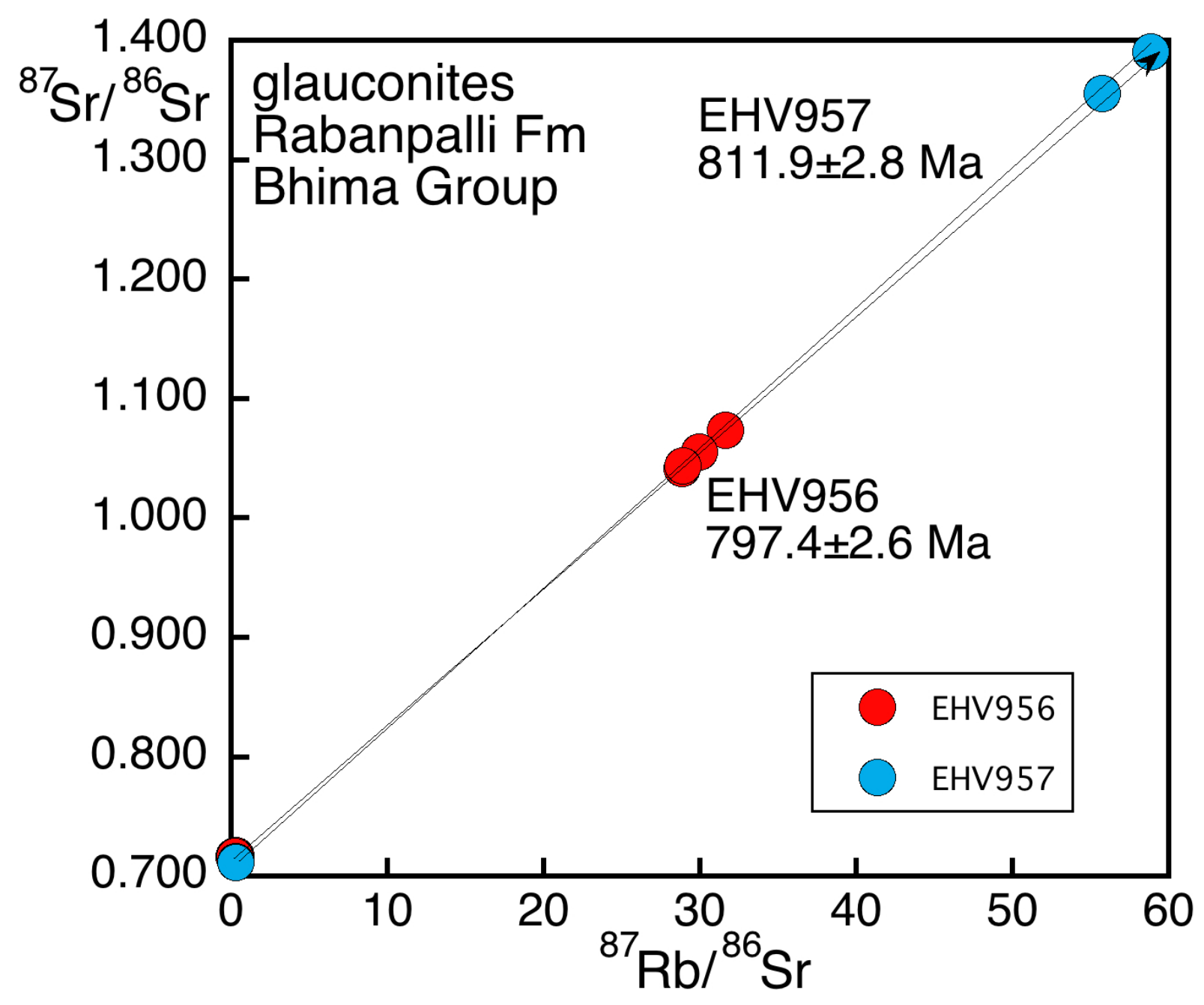

GJ_3415_F18.tif 